\title{
Diced Electrophoresis Gel assay for Screening Enzymes with Specified Activities
}

Toru Komatsu, Kenjiro Hanaoka, Alexander Adibekian, Kentaro Yoshioka, Takuya Terai, Tasuku Ueno, Mitsuyasu Kawaguchi, Benjamin F. Cravatt, and Tetsuo Nagano

\section{Methods}

Chemical synthesis and characterization. General chemicals were of the best grade available, supplied by Tokyo Chemical Industries, Wako Pure Chemical, Aldrich Chemical Co., and Invitrogen, and were used without further purification. ${ }^{1} \mathrm{H}$ NMR and ${ }^{13} \mathrm{C}$ NMR spectra were recorded on a JEOL JNM-LA300 instrument. $\delta$ values are in ppm relative to tetramethylsilane (TMS). Mass spectra (MS) were measured with a JEOL JMST100LC AccuTOF (ESI).

Enzymes. Enzymes were supplied by Sigma-Aldrich or Enzo Life Sciences. Enzymes were diluted in enzyme reaction buffer (pH 7.4 phosphate-buffered saline (PBS) containing $1 \mathrm{mM} \mathrm{CaCl}_{2}$ and $1 \mathrm{mM} \mathrm{MgCl}_{2}$ ) to suitable concentrations to perform assays. Details are as follows.

\begin{tabular}{|c|c|c|c|c|}
\hline Name & Source & Order No. & Lot No. & Activity \\
\hline$\beta$-Glucosidase & Almond & $\begin{array}{c}\text { Sigma-Aldrich } \\
49290\end{array}$ & BCBF2163V & 6.6 units / mg prot. \\
\hline$\beta$-Galactosidase & Escherichia coli & $\begin{array}{l}\text { Sigma-Aldrich } \\
\text { G6008 }\end{array}$ & $109 \mathrm{~K} 8618 \mathrm{~V}$ & 229 units / mg prot. \\
\hline $\begin{array}{c}\text { Alkaline } \\
\text { Phosphatase }\end{array}$ & $\begin{array}{c}\text { Bovine intestinal } \\
\text { mucosa }\end{array}$ & $\begin{array}{c}\text { Sigma-Aldrich } \\
\text { P5521 } \\
\end{array}$ & $038 \mathrm{~K} 1153$ & $\begin{array}{l}4750 \text { units / mg } \\
\text { prot. }\end{array}$ \\
\hline Esterase & Porcine liver & $\begin{array}{c}\text { Sigma-Aldrich } \\
\text { E2884 }\end{array}$ & $129 \mathrm{~K} 7010$ & 154 units / mg prot. \\
\hline Elastase & Porcine pancreas & $\begin{array}{c}\text { Sigma-Aldrich } \\
\text { E7885 }\end{array}$ & $011 \mathrm{M} 7026 \mathrm{~V}$ & 6 units / mg solid \\
\hline $\begin{array}{c}\text { Leucine } \\
\text { aminopeptidase }\end{array}$ & Porcine kidney & $\begin{array}{l}\text { Sigma-Aldrich } \\
\text { L5006 }\end{array}$ & $069 \mathrm{~K} 7356 \mathrm{~V}$ & $\begin{array}{l}\text { 10-40 units / } \mathrm{mg} \\
\text { prot. }\end{array}$ \\
\hline Proteasome S20 & Human & $\begin{array}{l}\text { Enzo Life Scences } \\
\text { PML-PW8720 }\end{array}$ & X09217 & \\
\hline
\end{tabular}

Generation of plasmids. Full-length mouse acylamino acid releasing enzyme (APEH) sequence was amplified from a cDNA library of mouse liver and cloned into pcDNA3.1 $(+)$ vector with restriction enzymes BamHI/XhoI for transformation into JM109 cells. PCR was performed with KOD Plus (Toyobo) following the standard protocol, with the following primers.

Forward primer: GATCGGATCCACCATGGAGCGTCAGGTGCTGCTGAGTGAGCC

Reverse primer: GATCCTCGAGTCAGCTGCCCAAGTGTGTGTGTAGCCAAAGCACAG 
HeLa cell culture and transfection. HeLa cells (ATCC) were cultured in Dulbecco's modified Eagle's medium (DMEM; Wako Pure Chemical) containing 10\% fetal bovine serum (FBS; Gibco). Transfection was performed with Lipofectamine LTX and PLUS reagents (Invitrogen). As the standard condition, $1 \mu \mathrm{g}$ plasmid, $1 \mu \mathrm{L}$ PLUS reagent, and $3 \mu \mathrm{L}$ lipofectamine LTX were mixed in $150 \mu \mathrm{L}$ Opti-MEM (Gibco) and added to $3 \mathrm{~mL}$ of cellular solution, and cells were used 1 day after transfection. Transfection efficiency was confirmed to be $30-60 \%$ using Clonetech-YFP (C1) plasmid as a control.

HL-60 cell culture and differentiation. HL-60 cells (ATCC) were cultured in RPMI-1640 (Gibco) containing $10 \%$ FBS. For differentiation to model neutrophils ${ }^{1}$, the cells were cultured in media containing $1.5 \%$ DMSO for 3-4 days. Differentiation was confirmed by means of cell migration study with fMLF (10 nM) as a stimulant.

Cell migration study. Fibronectin-coated dishes were prepared by incubating fibronectin solution $(100 \mu \mathrm{g} / \mathrm{mL}$; Sigma-Aldrich) on non-coated glass-bottomed dishes (Matsunami Glass) for 2-4 hours at room temperature, and washed three times with PBS. Differentiated HL-60 cells were plated on a fibronectin-coated dish in medium containing calcein AM (100 nM). After 30-120 min, cells were washed 5 times with Hank's balanced salt solution (HBSS; Gibco), and stimulant-containing HBSS was added. Bright-field and fluorescence images were acquired on an epifluorescence microscope (IX-71; Olympus) with appropriate filters. Cells were traced with the motion analysis macro on Metamorph.

Preparing cell lysates. Cells plated on a $10 \mathrm{~cm}$ plastic dish were washed twice with PBS. $1 \mathrm{~mL}$ PBS was added, and cells were scraped off and collected in a $1.5 \mathrm{~mL}$ plastic tube. After centrifugation $(1400 \mathrm{rpm} \times 3 \mathrm{~min}$ at $4^{\circ} \mathrm{C}$ ), the supernatant was removed, and $200 \mu \mathrm{L}$ enzyme reaction buffer ( $\mathrm{pH}$ 7.4 PBS containing $1 \mathrm{mM} \mathrm{CaCl}_{2}$ and $1 \mathrm{mM} \mathrm{MgCl}$ ) was added. Pellets were homogenized by sonication on ice with 5 pulses (3W power; 1 pulse $=1 \mathrm{sec}$ ) from a Sonicator S-4000 (Misonix). Protein concentration was determined with the standard Bradford assay (Bio-Rad 500-0006; BSA was used for calibration), and the lysates were aliquoted and kept at $80^{\circ} \mathrm{C}$. Each assay was performed with a single aliquot, so that repeated cycles of freeze-thawing were avoided.

Preparing mouse tissue lysates. Black mice (C57BL/6JJcl, male, 7-8 weeks old) were sacrificed, and tissues were collected and put in $1.5 \mathrm{~mL}$ plastic tubes. The tubes were freeze-dried in liquid nitrogen immediately after collection, and kept at $-80^{\circ} \mathrm{C}$. To prepare the lysate, freeze-dried tissues $(100-200 \mathrm{mg})$ were put in a glass homogenizer and $1 \mathrm{~mL}$ of enzyme reaction buffer ( $\mathrm{pH} 7.4 \mathrm{PBS}$ containing $1 \mathrm{mM} \mathrm{CaCl}$ and $1 \mathrm{mM} \mathrm{MgCl}_{2}$ ) was added. The tissues were homogenized, and the homogenate was put in $1.5 \mathrm{~mL}$ plastic tubes and centrifuged $\left(5000 \mathrm{rpm} \times 10 \mathrm{~min}\right.$ at $\left.4^{\circ} \mathrm{C}\right)$. The supernatant was collected as tissue lysate, and the protein concentration was determined with standard Bradford assay. The lysates were aliquoted and kept at $-80^{\circ} \mathrm{C}$. Each assay was performed with a single aliquot, so that repeated cycles of freeze-thawing were avoided. 
Enzymatic assay. If not otherwise mentioned, enzymatic assay was performed in enzyme reaction buffer ( $\mathrm{pH}$ 7.4 PBS containing $1 \mathrm{mM} \mathrm{CaCl}_{2}$ and $\left.1 \mathrm{mM} \mathrm{MgCl}_{2}\right)$ at $25^{\circ} \mathrm{C}$. Half-area 96-well plates (Costar 3694) were used for the assay (100 $\mu \mathrm{L}$ reaction volume). Fluorescence was detected with a plate reader, EnVision 2103 Multilabel Reader (Perkin Elmer), under appropriate filter conditions.

Diced electrophoresis gel (DEG) assay. For one-dimensional DEG assay, blue native PAGE was performed, and for two-dimensional DEG assay, isoelectric focusing (IEF) and blue native PAGE were performed. In all cases, the size of the electrophoresis gel was $10 \mathrm{~cm}$ x $10 \mathrm{~cm}$. After the electrophoresis, the gel was placed on a $0.5 \mathrm{~mm}$ square wire mesh over a 384-well plate (Eppendorf 0030 621.905), and fixed in place with the lid. Gels were covered with a polyethylene sheet (Kajix HC-P), taped, and diced by pressing down on the gel. Gels should be kept wet during the overall process to improve recovery. If necessary, a wide spatula can be used to ensure homogeneous dicing. Centrifugation (3000 rpm $\times 1 \mathrm{~min})$ was performed to load the diced gels into the 384-well plate, and assays were performed by adding $75 \mu \mathrm{L}$ of probe solution into wells. Fluorescence was read out with a plate reader, EnVision 2103 Multilabel Reader (Perkin Elmer), under appropriate filter conditions until a sufficient signal-to-noise ratio was achieved. In data analysis, spots with signals higher than (average) + $3.29 \times$ (S.D.) of background (eliminating $99.9 \%$ of false positives) are referred to as positive signals. The procedures were optimized as regards the size of the mesh wires, the type of plates, and the methods of dicing and loading to give high recovery and repeatability, but conditions could be varied if required for particular purposes, provided that the modified system is validated with model enzymes.

DEG assay for LC-MS-based reaction analysis. One-dimensional blue native PAGE was performed, and gel from each lane was loaded into different locations of the 384-well plate. Wells in rows corresponding to a single lane of the gel were filled with $75 \mu \mathrm{L}$ solution of analyte and internal standard, and the assay was performed for the indicated time. The reaction was quenched by adding $50 \mu \mathrm{L} 10 \%$ formic acid-methanol to all wells, and $20 \mu \mathrm{L}$ of the solution was injected for analysis in an LC-MS (Agilent 1200 series/6130 Quadrupole LC-MS). All experiments were performed in triplicate.

Two-dimensional DEG assay to characterize the targets of fMet-AMC and fMet-Leu-AMC. Twodimensional electrophoresis was performed for mouse liver lysate, and DEG assay was performed with fMetAMC $(10 \mu \mathrm{M})$ or fMet-Leu-AMC $(10 \mu \mathrm{M})$ in the enzyme reaction buffer. Total protein amount loaded on the gel was $25 \mu \mathrm{g}$ for fMet-AMC and $250 \mu \mathrm{g}$ for fMet-Leu-AMC. The well with the highest activity was identified after an appropriate incubation time (30 min for fMet-AMC and $18 \mathrm{hr}$ for fMet-Leu-AMC), and gel in the well was collected in a $1.5 \mathrm{~mL}$ tube. Collected gel was washed three times with pure water, and kept at $-20^{\circ} \mathrm{C}$. Gels from 3 independent assays were mixed for a single LC-MS/MS analysis. 
Protein digestion and LC-MS/MS analysis (peptide mass fingerprinting (PMF) analysis). LS-MS/MS-

based protein identification was performed as a contract service by APRO Life Science Institute, Inc. Samples were prepared by reductive alkylation and trypsin digestion following standard protocols. Peptides were separated on a Paradigm MS2 (Michrom BioResources, Inc.) equipped with an L-column ODS $(0.1 \times 50 \mathrm{~mm}$, Chemicals Evaluation and Research Institute) under an acidic solvent condition ( $0.1 \%$ formic acid) with an increasing gradient of acetonitrile.

Detection was done with a Q-Tof2 (Waters Micromass) in the positive mode (capillary voltage: $1.8 \mathrm{kV}$, collision energy: 20-56 ev).

Analysis of LC-MS/MS data. The acquired LC-MS/MS data was analyzed using MASCOT Server 2.3 (Matrix Science Ltd.) to find the hit proteins. The threshold was set at $\mathrm{P}<0.05$. The database to be searched can be that for all species, but when the scores of proteins were low due to the presence of contaminating proteins such as keratins and trypsin, we limited the search to the database of mouse, the source animal of the tissue samples. To identify the candidate target of fMet-AMC (as APEH), we used the database of proteins from all species. To identify the candidate target of fMet-Leu-AMC (as proteasome), we used only the mouse database. The list of hit proteins may contain multiple proteins in addition to the true target, so available information on all hit proteins in the literature and in enzyme databases (BRENDA; http://www.brendaenzymes.org/) was scanned to identify those likely to accept the probes as substrates. The selected candidate protein(s) were validated by biochemical methods using purified or overexpressed proteins, inhibitors and antibodies, as described in the main text. 
Protocols for Electrophoresis. If not otherwise mentioned, electrophoresis was performed at $4{ }^{\circ} \mathrm{C}$ following the standard protocols supplied by the manufacturer. Detailed information is as follows.

\begin{tabular}{|c|c|c|c|c|c|}
\hline Name & Gels & Sample buffer & Running buffer & Voltage & Time \\
\hline $\begin{array}{l}\text { SDS- } \\
\text { PAGE }\end{array}$ & $\begin{array}{c}\text { Multigel II mini } \\
\text { (Cosmo Bio 414909) }\end{array}$ & $\begin{array}{c}\text { Tris SDS } \beta \text {-ME } \\
\text { sample buffer } \\
\text { (Cosmo Bio } \\
\text { 423437) }\end{array}$ & SDS-Tris-glycine buffer & $200 \mathrm{~V}$ & $1 \mathrm{hr}$ \\
\hline \multirow{2}{*}{$\begin{array}{l}\text { Isoelectric } \\
\text { Focusing }\end{array}$} & \multirow{2}{*}{$\begin{array}{c}\text { pH 3-10 IEF gels } \\
\text { (Invitrogen EC66552 } \\
\text { BOX) }\end{array}$} & \multirow{2}{*}{$\begin{array}{l}\mathrm{pH} 3-10 \text { IEF } \\
\text { sample buffer } \\
\text { (Invitrogen } \\
\text { LC5311) }\end{array}$} & \multirow{2}{*}{$\begin{array}{l}\text { Cathode: } \\
20 \mathrm{mM} \text { L-arginine } \\
20 \mathrm{mM} \text { L-lysine } \\
\text { Anode: } \\
7 \mathrm{mM} \text { phosphoric acid }\end{array}$} & $100 \mathrm{~V}$ & $0.5 \mathrm{hr}$ \\
\hline & & & & $300 \mathrm{~V}$ & $2.5 \mathrm{hr}$ \\
\hline $\begin{array}{l}\text { Native } \\
\text { PAGE }\end{array}$ & $\begin{array}{l}\text { 4-16\% Bis-Tris gels } \\
\text { (Invitrogen } \\
\text { BN1004BOX) }\end{array}$ & $\begin{array}{l}\text { Native PAGE } \\
\text { sample buffer } \\
\text { (Invitrogen } \\
\text { BN2003) }\end{array}$ & $\begin{array}{l}\text { Native PAGE running } \\
\text { buffer } \\
\text { (Invitrogen BN2001) }\end{array}$ & $200 \mathrm{~V}$ & $2 \mathrm{hr}$ \\
\hline $\begin{array}{l}\text { Blue } \\
\text { Native } \\
\text { PAGE }\end{array}$ & $\begin{array}{l}4-16 \% \text { Bis-Tris gels } \\
\text { (Invitrogen } \\
\text { BN1004BOX) }\end{array}$ & $\begin{array}{l}\text { Native PAGE } \\
\text { sample buffer } \\
\text { (Invitrogen } \\
\text { BN2003) }\end{array}$ & $\begin{array}{l}\text { Cathode: } \\
\text { Native-PAGE running } \\
\text { buffer }+0.4 \% \\
\text { Coomassie G-250 } \\
\text { Anode: } \\
\text { Native-PAGE running } \\
\text { buffer }\end{array}$ & $200 \mathrm{~V}$ & $2 \mathrm{hr}$ \\
\hline
\end{tabular}

Molecular weight standard and CBB staining of blue native PAGE gels. NativeMark unstained protein standard (Invitrogen LC0725) was used as a molecular weight standard for blue native PAGE. For CBB staining of blue native PAGE gel, extra electrophoresis was performed after standard blue native PAGE in order to remove Coomassie G-250 from the gel. The extra electrophoresis was performed in native PAGE buffer (without Coomassie G-250) at $200 \mathrm{~V}$ (constant) for $2 \mathrm{hr}$. Due to the high resistance of the gel after blue native PAGE, the current remained at 1-3 mA, and protein bands did not move significantly with or without the procedure. The gel was incubated for $30 \mathrm{~min}$ in CBB staining solution (Coomassie R-250; Cosmo-bio) and washed three times with distilled water. The gel was incubated for 1 day in distilled water for complete washout and imaged with an ImageQuant CAS 4000 mini (GE Healthcare).

Renaturing proteins in SDS-PAGE gels. SDS-PAGE gel was washed with 2.5\% Triton X-100 for 30 min, and washed three times with distilled water. The gel was further incubated with developing buffer (Invitrogen LC2671) for $30 \mathrm{~min}$, and washed three times with distilled water. 
Western blotting. After the blue native PAGE, proteins were transferred onto PVDF membrane (Bio-Rad) following the standard western blotting protocol. After the transfer, the membrane was washed with $50 \%$ methanol- $\mathrm{H}_{2} \mathrm{O}$ several times until Coomassie G-250 was washed out. After blocking of the membrane with skim milk, the membrane was incubated in blocking solution containing 1st antibody (Santa Cruz sc-102311; $1 / 500$ dilution) at $4^{\circ} \mathrm{C}$ for $18 \mathrm{hr}$, washed three times with PBS containing $0.01 \%$ Tween 20 (PBS-T), and incubated in PBS-T containing 2nd antibody (Sigma-Aldrich A5420; 1/2000 dilution) at room temperature for 2 hr. The membrane was washed three times with PBS-T, and then chemiluminescence reaction was performed with the use of ECL Prime western blotting detection reagent (Amersham). Detection was done with an ImageQuant CAS 4000 mini (GE Healthcare).

Conventional zymography with colorimetric substrates. After blue native PAGE of $\beta$-galactosidase (3-300 ng), Coomassie G-250 was removed from the electrophoresis gel by extra electrophoresis as in the case of CBB staining. The gel was then washed three times with distilled water, and stained with standard X-gal staining solution (Sigma-Aldrich GALS) at $37^{\circ} \mathrm{C}$ for $2 \mathrm{hr}$. The gel was washed three times with distilled water, and imaged with an ImageQuant CAS 4000 mini (GE Healthcare).

Conventional zymography with fluorescent substrates. $2 \%$ Agarose (SeaKem GTG agarose; Takara Bio) solution in $10 \mathrm{~mL}$ distilled water was prepared by heating in a microwave oven, and then cooled to $50^{\circ} \mathrm{C}$. Probe solution in $10 \mathrm{~mL}$ of enzyme reaction buffer was mixed with the agarose solution, and the mixture was poured onto blue native PAGE gel containing the indicated concentrations of enzyme. After 18 hours, fluorescence images were taken with appropriate instruments. For fluorescent probes based on fluorescein and TokyoGreen scaffolds, fluorescence images were taken with a Maestro in vivo imaging system (CRi) under appropriate filter conditions. For fluorescent probes based on the coumarin scaffold, fluorescence images were taken with a digital camera while the gel was irradiated with a handy UV lamp $(365 \mathrm{~nm})$. In both cases, detectability was better than could be obtained with naked eye observation.

LC-MS-based study of fMLF metabolism. fMLF (final $20 \mu \mathrm{M}$ ) and 2-methyl-4-methoxy-TokyoGreen (internal standard; final $0.1 \mu \mathrm{M}$ ) were mixed with cell lysates or mouse tissue lysates, and incubated for the indicated times. For inhibitor treatment samples, lysates were incubated with AA74-1 (final $100 \mathrm{nM}$ ) for $30 \mathrm{~min}$ or proteasome inhibitor (lactacystin, bortezomib, or MG-132) for $1.5 \mathrm{hr}$ before the reaction, and an equivalent amount of DMSO was added as a vehicle. The reaction was terminated by adding a 4 -fold excess of $10 \%$ formic acid-methanol, and a $20 \mu \mathrm{L}$ aliquot was injected for LC-MS analysis (Agilent 1200 series/6130 Quadrupole LC/MS) on an ODS-3 column (GL Sciences) under an acidic solvent condition ( $0.1 \%$ formic acid) with an increasing gradient of acetonitrile. Detection was performed in the positive mode, and linearity of the signal was confirmed by the use of a reference standard. The decrease of fMLF was determined by analyzing the peak area of chromatograms $(\mathrm{m} / \mathrm{z}=$ value \pm 0.5$)$ using that of 2-methyl-4-methoxy-TokyoGreen as an internal standard. Concentrations of formyl-methionine (fMet) and formyl-methionyl-leucine (fML) were determined with using the purified compounds as reference standards. 
Live cell imaging. HeLa cells transfected with mouse APEH plasmid and treated with or without AA74-1 (100 $\mathrm{nM})$ for 30 min were washed three times with PBS, and incubated with fMet-Rhod (10 $\mu \mathrm{M})$ in HBSS.

Fluorescence images were taken on a confocal microscope (TCS SP-5; Leica) with appropriate optical conditions.

In vivo imaging. Nude mice (BALB/cAJcl-nu/nu, female, 7-8 weeks old) were anesthetized under isoflurane, and saline (vehicle; $100 \mu \mathrm{L})$ or AA74-1 in saline $(650 \mu \mathrm{M}, 100 \mu \mathrm{L})$ was intravascularly injected from the eye. After $4 \mathrm{hr}$, mice were anesthetized by intraperitoneal administration of pentobarbital, and fMet-Rhod $(100 \mu \mathrm{M}$, $100 \mu \mathrm{L}$ ) were intravascularly injected from the eye. The skin on the ventral side was cut off, and fluorescence images were taken from the ventral side with a Maestro in vivo imaging system (CRi) under appropriate filter conditions. Experiments were performed 3 times for vehicle or AA74-1-treated conditions. 


\section{Supporting Methods for Chemical Synthesis and Characterization of Compounds}

Synthesis of fMet-AMC and fMet-Leu-AMC.

General procedure of formyl-methionyl amide formation. Amine was dissolved in $2 \mathrm{~mL}$ of $\mathrm{N}, \mathrm{N}$ dimethylformamide (DMF), and $N$-formyl-L-methionine (2.0 eq.), 2-(1H-7-azabenzotriazol-1-yl)-1,1,3,3tetramethyluronium hexafluorophosphate methanaminium (HATU, 1.2 eq.), $\mathrm{N}, \mathrm{N}$-diisopropyl- $\mathrm{N}$-ethylamine (DIEA, 6.0 eq.) were added. The mixture was stirred under an argon atmosphere at room temperature overnight. Ethyl acetate $(20 \mathrm{~mL})$ was added, and the organic layer was washed with brine three times, dried over $\mathrm{Na}_{2} \mathrm{SO}_{4}$, filtered, and evaporated to give a crude product. Purification was performed with column chromatography (silica; $\mathrm{CH}_{2} \mathrm{Cl}_{2}-5 \%$ methanol) or preparative HPLC until the pure product was acquired.

Preparation of fMet-AMC (1). fMet-AMC was prepared from 7-amino-4-methylcoumarin (33 mg, 0.17 mmol). Column chromatography afforded pure 1 (25 mg, 45\%) as a colorless solid. ${ }^{1} \mathrm{H}$ NMR (300 MHz, DMSO- $\left.d_{6}\right): \delta 1.7-2.2(\mathrm{~m}, 2 \mathrm{H}) ; 2.07(\mathrm{~s}, 3 \mathrm{H}) ; 2.40(\mathrm{~s}, 3 \mathrm{H}) ; 2.3-2.5(\mathrm{~m}, 2 \mathrm{H}) ; 4.58(\mathrm{~m}, 1 \mathrm{H}) ; 6.28(\mathrm{~s}, 1 \mathrm{H}) ; 7.50(\mathrm{dd}$, $1 \mathrm{H}, J=8.1,1.8 \mathrm{~Hz}) ; 7.72(\mathrm{~d}, 1 \mathrm{H}, J=8.1 \mathrm{~Hz}) ; 7.78(\mathrm{~d}, 1 \mathrm{H}, J=1.8 \mathrm{~Hz}) ; 8.05(\mathrm{~s}, 1 \mathrm{H}) ; 8.56(\mathrm{~d}, 1 \mathrm{H}, J=4.8 \mathrm{~Hz})$; $10.58(\mathrm{~s}, 1 \mathrm{H})$. HRMS $\left(\mathrm{ESI}^{+}\right): \mathrm{m} / z$ calcd. for $(\mathrm{M}+\mathrm{Na})^{+}, 357.0885$; found, 357.0868 .

Preparation of fMet-Leu-AMC (2). fMet-Leu-AMC was prepared from Leu-AMC (15 mg, $0.052 \mathrm{mmol})$. Preparative HPLC afforded pure $2(17 \mathrm{mg}, 72 \%)$ as a colorless solid. ${ }^{1} \mathrm{H}$ NMR (300 MHz, DMSO- $\left.d_{6}\right): \delta 0.90$ $(\mathrm{m}, 6 \mathrm{H}) ; 1.5-2.0(\mathrm{~m}, 5 \mathrm{H}) ; 2.03(\mathrm{~s}, 3 \mathrm{H}) ; 2.3-2.4(\mathrm{~m}, 2 \mathrm{H}) ; 2.40(\mathrm{~s}, 3 \mathrm{H}) ; 4.3-4.7(\mathrm{~m}, 2 \mathrm{H}) ; 6.28(\mathrm{~s}, 1 \mathrm{H}) ; 7.52(\mathrm{~d}, 1 \mathrm{H}$, $J=8.4 \mathrm{~Hz}) ; 7.68(\mathrm{~d}, \mathrm{H}, J=8.4 \mathrm{~Hz}) ; 7.78(\mathrm{~s}, 1 \mathrm{H}) ; 8.04(\mathrm{~s}, 1 \mathrm{H}) ; 8.35(\mathrm{~d}, 1 \mathrm{H}, J=8.4 \mathrm{~Hz}) ; 10.46(\mathrm{~s}, 3 \mathrm{H})$. HRMS $\left(\mathrm{ESI}^{+}\right): m / z$ calcd. for $(\mathrm{M}+\mathrm{Na})^{+}, 470.1726$; found, 470.1725 .

Preparation of fMet-Rhod (3). fMet-Rhod was prepared from rhodamine $123(20 \mathrm{mg}, 0.061 \mathrm{mmol})$. Preparative HPLC and column chromatography afforded pure $3(9.1 \mathrm{mg}, 23 \%)$ as a colorless solid. ${ }^{1} \mathrm{H}$ NMR (300 MHz, DMSO-d $\left.d_{6}\right): \delta 2.0-2.2(\mathrm{~m}, 4 \mathrm{H}) ; 2.08(\mathrm{~s}, 6 \mathrm{H}) ; 2.58(\mathrm{~m}, 4 \mathrm{H}) ; 4.77(\mathrm{~m}, 2 \mathrm{H}) ; 6.79(\mathrm{~d}, 2 \mathrm{H}, J=8.7 \mathrm{~Hz})$; $7.25(\mathrm{~m}, 4 \mathrm{H}) ; 7.72(\mathrm{~m}, 4 \mathrm{H}) ; 7.9-8.1(\mathrm{~m}, 1 \mathrm{H}) ; 8.23(\mathrm{~d}, 1 \mathrm{H}, J=8.1 \mathrm{~Hz}) ; 9.69(\mathrm{~s}, 2 \mathrm{H})$. HRMS (ESI $\left.{ }^{+}\right): m / z$ calcd. for $(\mathrm{M}+\mathrm{H})^{+}, 649.1785$; found, 649.1792 . 


\section{$\underline{\text { Supporting Schemes }}$}

\begin{tabular}{|l|l|}
\hline Supporting Scheme S1 & Synthetic schemes of fMet-AMC, fMet-Leu-AMC, and fMet-Rhod. \\
\hline Supporting Scheme S2 & Design of fluorescent substrates to visualize fMLF metabolizing reactions. \\
\hline
\end{tabular}<smiles>CSCC[C@H](NC(=O)C=O)C(=O)Nc1ccc2c(C)cc(=O)oc2c1</smiles><smiles>CSCC[C@H](NC(=O)CSc1ccc2c(C)cc(=O)oc2c1)C(=O)NC(CC(C)C)C(=O)Nc1ccc2c(C)cc(NC(=O)C(N)CC(C)C)cc2c1</smiles>

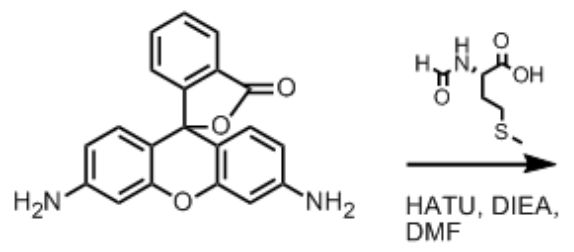<smiles>CSCCC(NC(=O)O)C(=O)Nc1ccc2c(c1)Oc1cc(NC(=O)C(CCSC)NC(=O)C=O)ccc1C21OC(=O)c2ccccc21</smiles>

Scheme S1. Synthetic schemes of fMet-AMC, fMet-Leu-AMC, and fMet-Rhod. 
(a)

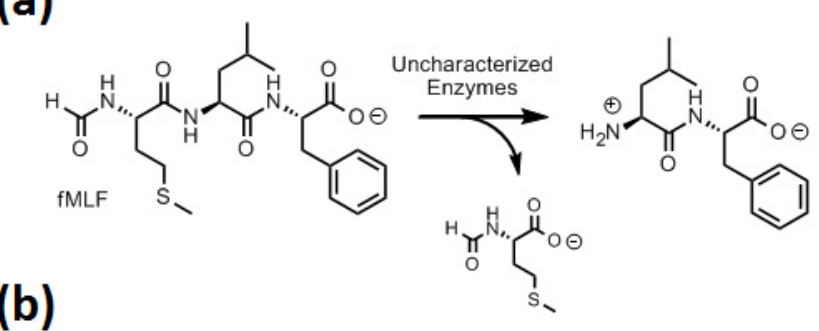

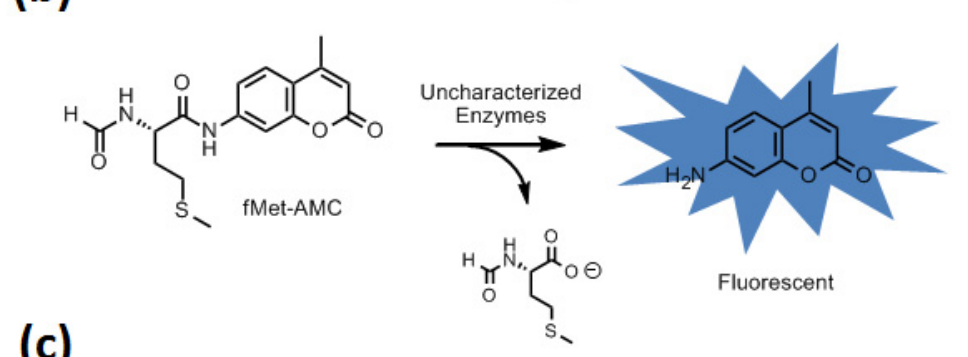

(c)

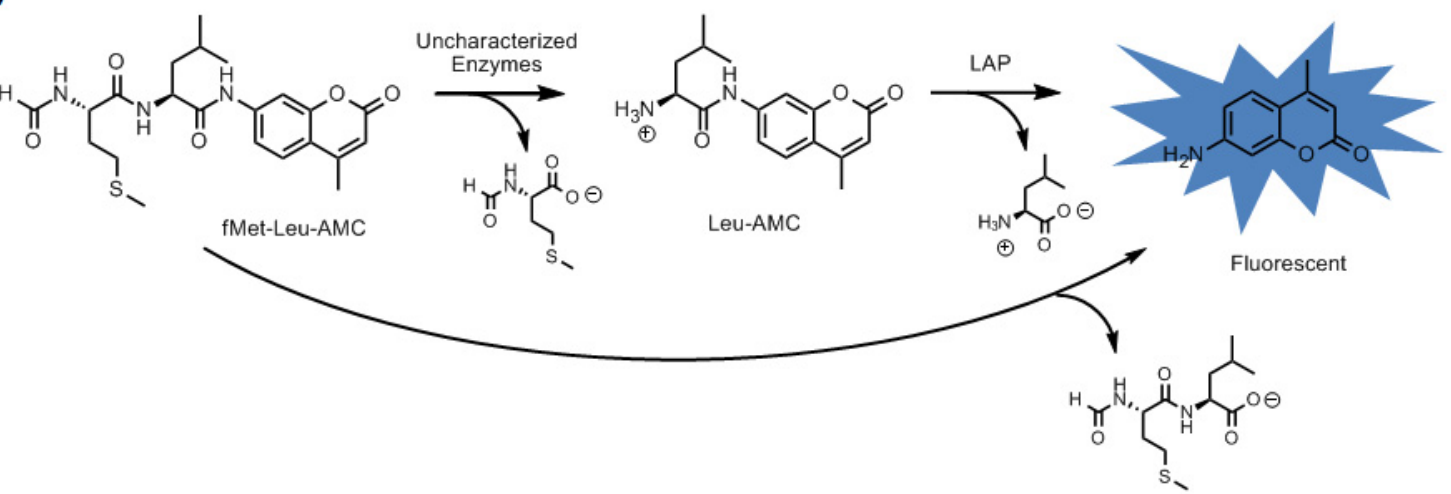

Scheme S2. Design of fluorescent substrates to visualize fMLF-metabolizing reactions. (a) Known metabolic inactivation of fMLF in living samples ${ }^{2}$. (b) Design of fMet-AMC to visualize cleavage of formyl-methionyl amide. (c) Design of fMet-Leu-AMC to visualize formyl-methionyl amide cleavage by coupled reaction with leucine aminopeptidase (LAP) or to directly detect formyl-methionyl-leucyl amide cleavage. 


\section{Supporting Experiments and Figures}

\begin{tabular}{|c|c|}
\hline Supporting Figure S1 & Results of DEG assay of $\beta$-glucosidase and $\beta$-galactosidase. \\
\hline Supporting Figure S2 & Results of DEG assay of alkaline phosphatase. \\
\hline Supporting Figure S3 & Development of suitable fluorescent substrate for DEG assay of liver esterases. \\
\hline Supporting Figure S4 & Results of DEG assay of elastase and leucine aminopeptidase. \\
\hline Supporting Figure S5 & $\begin{array}{l}\text { Evaluation of activity recovery in DEG assay based on different modes of } \\
\text { electrophoresis. }\end{array}$ \\
\hline Supporting Figure S6 & $\begin{array}{l}\text { Results of DEG assay of cell lysate of } \beta \text {-galactosidase-overexpressing HEK } 293 \\
\text { cells. }\end{array}$ \\
\hline Supporting Figure S7 & LC-MS-based analysis of fMLF cleavage in mouse liver lysate. \\
\hline Supporting Figure S8 & $\begin{array}{l}\text { Evaluation of enzymatic activities for fMet-AMC and fMet-Leu-AMC cleavage } \\
\text { in mouse tissue lysates. }\end{array}$ \\
\hline Supporting Figure S9 & Optimization of protein loading in native PAGE of mouse liver lysate. \\
\hline Supporting Figure S10 & $\begin{array}{l}\text { Results of DEG assay of mouse liver lysate with fMet-AMC and fMet-Leu- } \\
\text { AMC. }\end{array}$ \\
\hline Supporting Figure S11 & Results of LC-MS/MS analysis of the target enzyme of fMet-AMC. \\
\hline Supporting Figure S12 & $\begin{array}{l}\text { Results of two-dimensional DEG assay of cell lysate of HeLa cells transfected } \\
\text { with APEH plasmid. }\end{array}$ \\
\hline Supporting Figure S13 & $\begin{array}{l}\text { Results of two-dimensional electrophoresis of mouse APEH for CBB staining, } \\
\text { western blotting, and DEG assay. }\end{array}$ \\
\hline Supporting Figure S14 & $\begin{array}{l}\text { LC-MS-based analysis of fMLF cleavage in cell lysate of HeLa cells } \\
\text { transfected with or without mouse APEH plasmid. }\end{array}$ \\
\hline Supporting Figure S15 & $\begin{array}{l}\text { LC-MS-based analysis of fMLF cleavage in mouse liver lysate treated with or } \\
\text { without AA74-1. }\end{array}$ \\
\hline Supporting Figure S16 & Result of LC-MS/MS analysis of the target enzyme of fMet-Leu-AMC. \\
\hline Supporting Figure S17 & $\begin{array}{l}\text { Effect of proteasome inhibitors on DEG assay of mouse liver lysates with fMet- } \\
\text { Leu-AMC. }\end{array}$ \\
\hline Supporting Figure S18 & Fluorescence substrate-based evaluation of proteasome activity and inhibition. \\
\hline Supporting Figure S19 & $\begin{array}{l}\text { LC-MS-based analysis of fMLF cleavage by proteasome and mouse liver lysate } \\
\text { treated with or without proteasome inhibitors. }\end{array}$ \\
\hline Supporting Figure S20 & Effect of fMLF metabolism on chemotaxis of differentiated HL-60 cells. \\
\hline Supporting Figure S21 & $\begin{array}{l}\text { Overlay of bright field and fluorescence images of HeLa cells transfected with } \\
\text { mouse APEH and incubated with fMet-Rhod }\end{array}$ \\
\hline
\end{tabular}


DEG assay of glycosidases. Among glycosidases, we chose $\beta$-glucosidase and $\beta$-galactosidase, and 4-methylumbelliferyl- $\beta$-glucopyranoside (Umb $\beta$-Glc) and TG $\beta$-Gal were selected as substrates.

The two enzymes could be detected simultaneously because of the difference of fluorescence wavelengths of substrates (Figure S1). Detection limit was $1 \mathrm{ng}$ for $\beta$-glucosidase and $0.03 \mathrm{ng}$ for $\beta$-galacosidase.

(a)
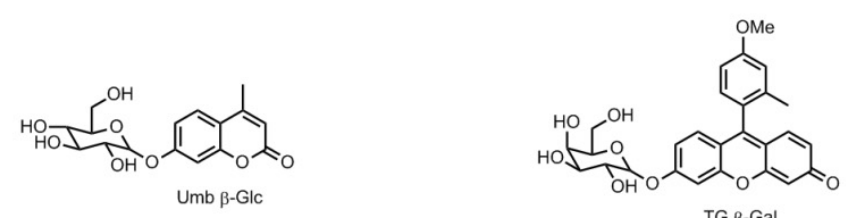

(b)
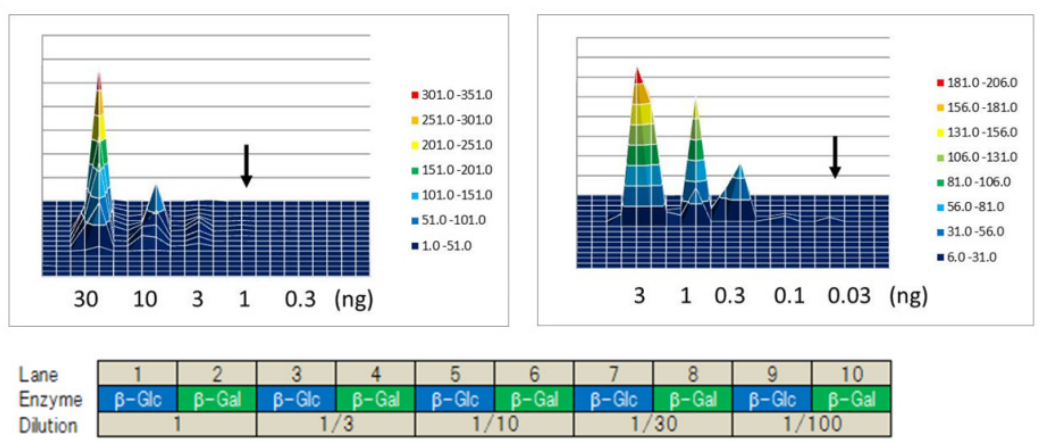

(c)
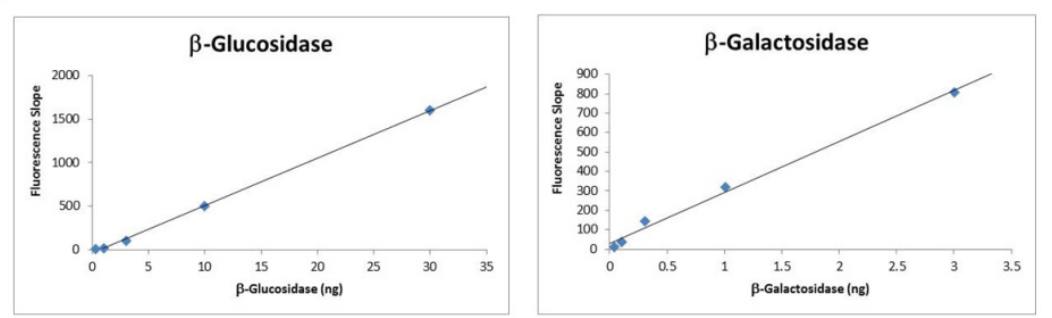

(d)

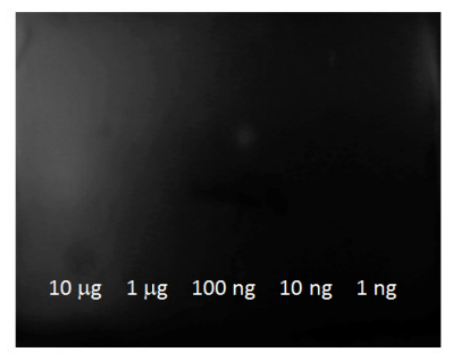

Figure S1. Results of DEG assay of $\beta$-glucosidase and $\beta$-galactosidase. (a) Structures of probes used in the study. (b) The result of one-dimensional DEG assay of $\beta$-glucosidase (detected with $100 \mu \mathrm{M} \mathrm{Umb} \beta$-Glc; lanes with odd numbers) and $\beta$-galactosidase (detected with $10 \mu \mathrm{M} \mathrm{TG} \beta$-Gal; lanes with even numbers). (c) Correlation of the protein amount and the sum of fluorescence increase rates of wells containing the enzymes. (d) Detection of $\beta$-glucosidase with fluorescent substrate Umb $\beta$-glc after blue native PAGE. 
DEG assay for esterases. Among esterases, we chose alkaline phosphatase (ALP) and porcine liver esterases (PLE), and the corresponding probes were 4-methyl-umbelliferyl phosphate (Umb Phos) and fluorescein diacetate (FDA). We could detect $0.3 \mathrm{ng}$ of alkaline phosphatase (Figure S2), while fluorescein diacetate failed to detect the activity of PLE unless a huge amount of proteins was loaded. This was because of background cleavage of the acetyl group on the gel; we think the polyacrylamide acted as a nucleophilic catalyst (Figure S3). In order to increase the signal-to-noise ratio, we synthesized more stable probes, and found that fluorescein dibutylate $(\mathrm{FDBu})$ was sufficiently stable on the gel. The use of FDBu, though it had a slower reaction rate with PLE, led to an improved signal-to-noise ratio, which enabled the detection of $10 \mathrm{ng}$ protein.

(a)

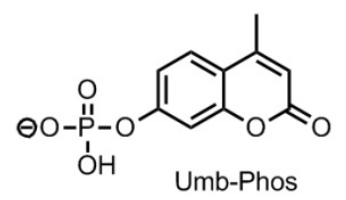

(b)

(c)
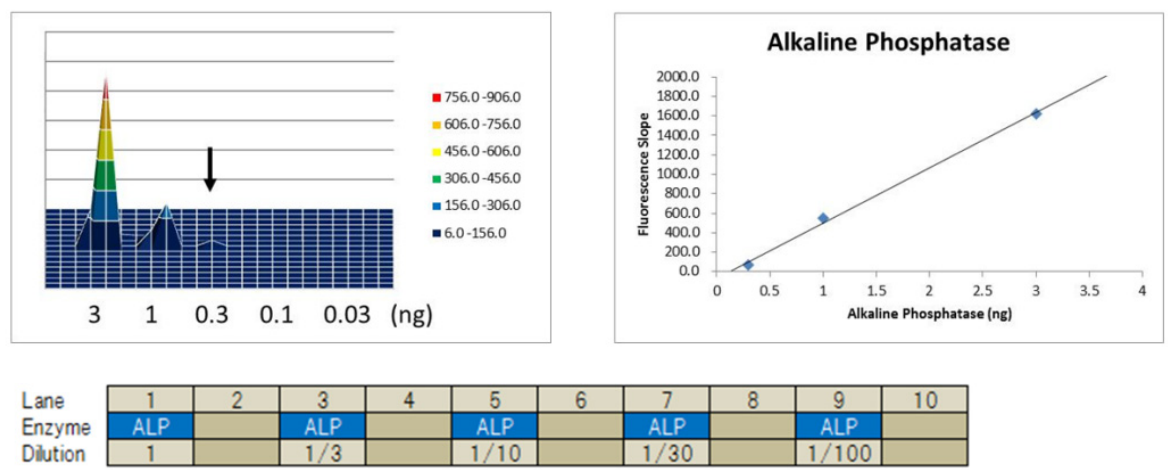

(d)

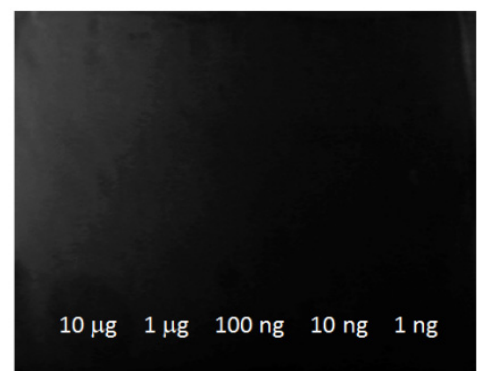

Figure S2. Results of DEG assay of alkaline phosphatase. (a) Structure of 4-methyl-umbelliferyl phosphate (Umb Phos). (b) The result of one-dimensional DEG assay of alkaline phosphatase (detected with $100 \mu \mathrm{M}$ Umb Phos). (c) Correlation of the protein amount and the sum of fluorescence increase rates of wells containing the enzyme. (d) Detection of alkaline phosphatase with fluorescent substrate Umb Phos after blue native PAGE. 
(a)

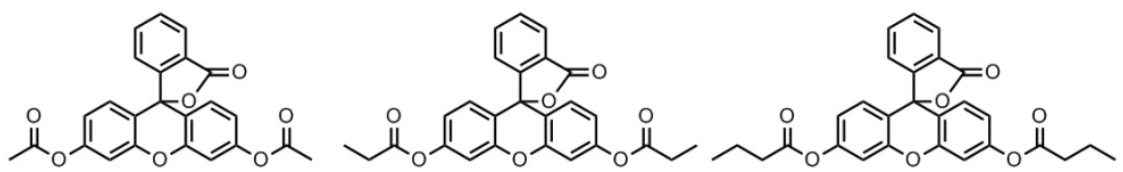

FDA

FDPr

FDBu

(b)

(c)
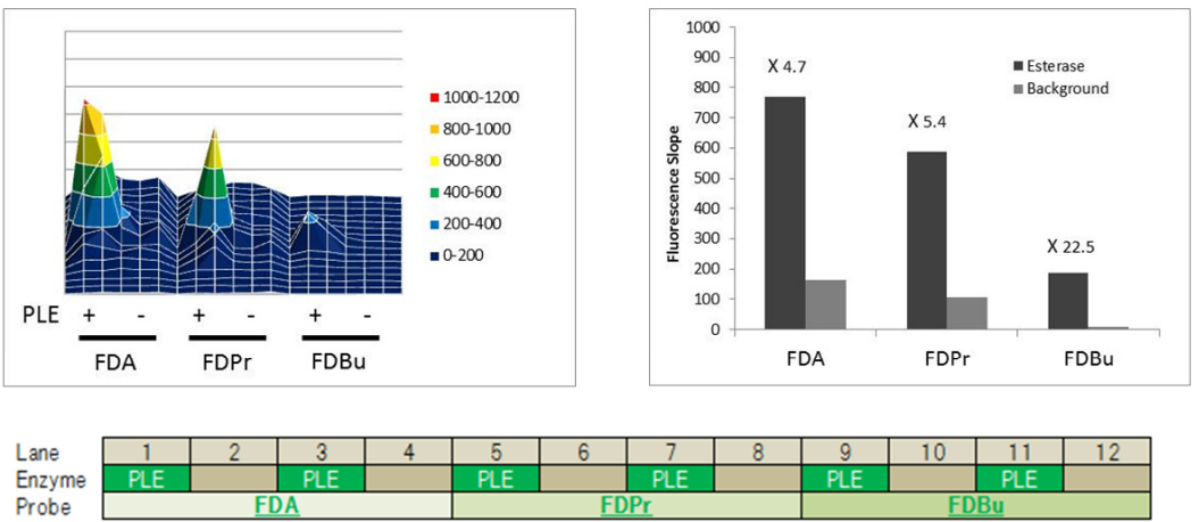

(d)

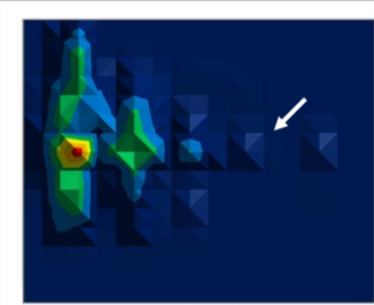

$10 \mu \mathrm{g} \quad 1 \mu \mathrm{g} \quad 100 \mathrm{ng} \quad 10 \mathrm{ng} \quad 1 \mathrm{ng}$ (e)

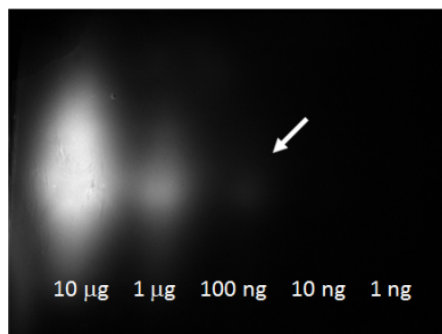

Figure S3. Development of suitable fluorescent substrate for DEG assay of liver esterases. (a) Structures of fluorescein diacetate (FDA), fluorescein dipropionate (FDPr), and fluorescein dibutyrate (FDBu), used to detect carboxylesterase activities on the gel. (b) The result of one-dimensional DEG assay of porcine liver esterase (PLE; $100 \mathrm{ng}$ ), including the background fluorescence increase. Background fluorescence increase was observed for FDA and FDPr. (c) Quantification of fluorescence increase rates of the probes on electrophoresis gel of (b) with or without enzymes. The number indicates the calculated signal-to-noise ratio. Notice that FDBu gave the best signal-to-noise ratio due to lower background signals. (d) The result of one-dimensional DEG assay of different concentrations of PLE (detected with $10 \mu \mathrm{M}$ FDBu). The white arrow indicates the smallest detectable fluorescent spot. (e) Detection of PLE with conventional zymography. The white arrow indicates the smallest detectable fluorescent spot. 
DEG assay for peptidases. Among peptidases, elastase and leucine aminopeptidase (LAP) were chosen, and the corresponding probes were MeO-Suc-Ala-Ala- Pro-Ile-AMC and Leu-AMC, respectively. While both probes had the same wavelength range, bands from these proteins were separately detected due to the difference of molecular weight of the two proteins. For elastase, the detection limit was $3 \mathrm{ng}$, and for LAP, the detection limit was $0.3 \mathrm{ng}$ (Figure S4).

(a)

(b)
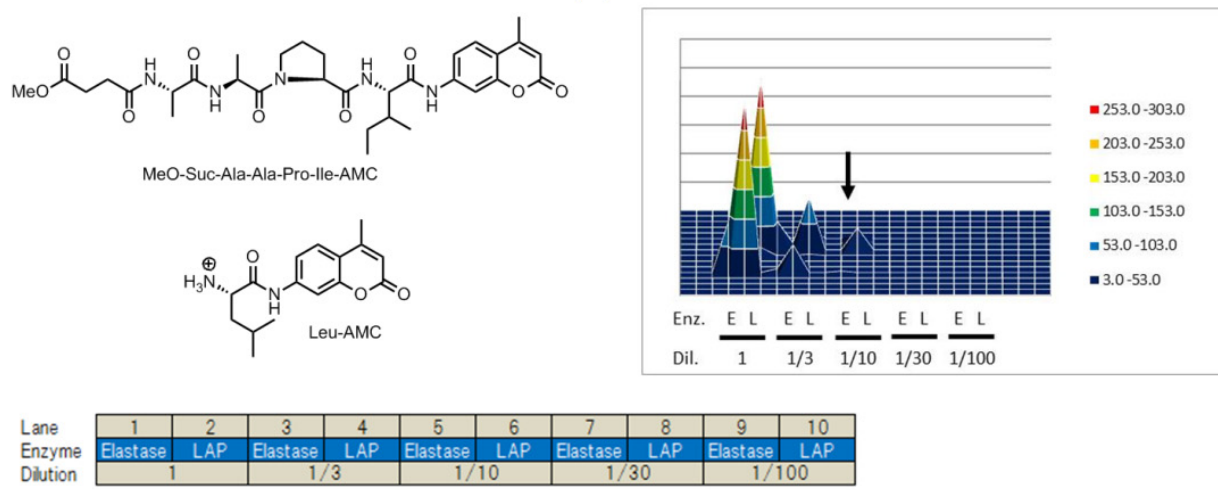

(c)
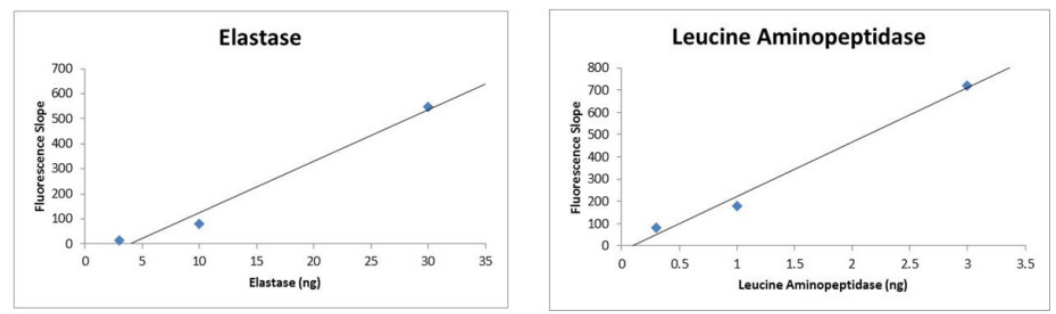

(d)
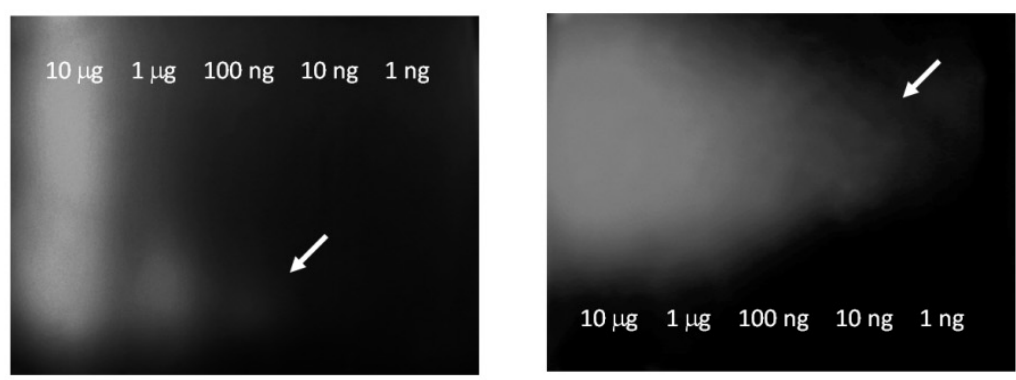

Figure S4. Results of DEG assay of elastase and leucine aminopeptidase. (a) Structures of probes used in the study. (b) The result of simultaneous one-dimensional DEG assay of elastase (detected with $50 \mu \mathrm{M} \mathrm{MeO-Suc-}$ Ala-Ala-Pro-Ile-AMC; $1 \times$ dilution was $30 \mathrm{ng}$ ) and leucine aminopeptidase (LAP; detected with $50 \mu \mathrm{M}$ LeuAMC; $1 \times$ dilution was $3 \mathrm{ng}$ ). (c) Correlation of the protein amount and the sum of fluorescence increase rates of wells containing the enzymes. (d) Detection of elastase and LAP with conventional zymography. The white arrow indicates the smallest detectable fluorescent spot. 
Modes of electrophoresis. Electrophoresis was performed as described in the Methods section. DEG assay was performed to detect the spots of active proteins, and the sum of activity was compared with the the activity in solution. All experiments were repeated twice, and the average activity recovery is graded alphabetically in Figure S5. In blue native PAGE, all tested proteins retained activity, and in isoelectric focusing (IEF), all proteins except for elastase retained activity. Elastase is known to be unstable under basic conditions due to self-digesting activity ${ }^{3}$, so the activity seemed to have been lost as a result of the basicity of buffers used in IEF.

\begin{tabular}{|c|c|c|c|c|c|c|}
\hline \multirow[b]{2}{*}{ Enzymes } & \multicolumn{2}{|c|}{ Glycosidases } & \multicolumn{2}{|c|}{ Esterases } & \multicolumn{2}{|c|}{ Peptidases } \\
\hline & $\beta$-Glucosidase & $\beta$-Galactosidase & Phosphatase & Esterase & Elastase & $\begin{array}{l}\text { Leucine } \\
\text { Aminopeptidase }\end{array}$ \\
\hline SDS-PAGE & & $\mathrm{D}$ & $\mathrm{C}$ & & & \\
\hline $\begin{array}{c}\text { SDS-PAGE } \\
\text { (Renature) }\end{array}$ & D & D & D & & & \\
\hline Native PAGE & $\mathrm{C}$ & B & $A$ & B & & A \\
\hline Blue native PAGE & B & B & A & $\mathrm{C}$ & A & A \\
\hline IEF & $A$ & $A$ & $B$ & C & & A \\
\hline
\end{tabular}

\section{$A=76-100 \% ; B=51-75 \% ; C=26-50 \% ; D=1-25 \% ;-=$ Not Detectable}

Figure S5. Evaluation of activity recovery in DEG assay employing different modes of electrophoresis. The results for 6 test enzymes are shown. See Figure 1h and Figure S1-S4 for details of proteins and fluorescent probes used. 
Determination of protein loading on blue native PAGE. When cell lysate was run on blue native PAGE, excessive protein loading resulted in an extended band due to tailing. Therefore, in order to obtain good resolution, blue native PAGE was performed after diluting cell lysates to different protein concentrations. In DEG assay, a good signal-to-noise ratio was observed even in diluted samples, while, in conventional zymography, diffusion made it difficult to detect signals (Figure S6).

(a)

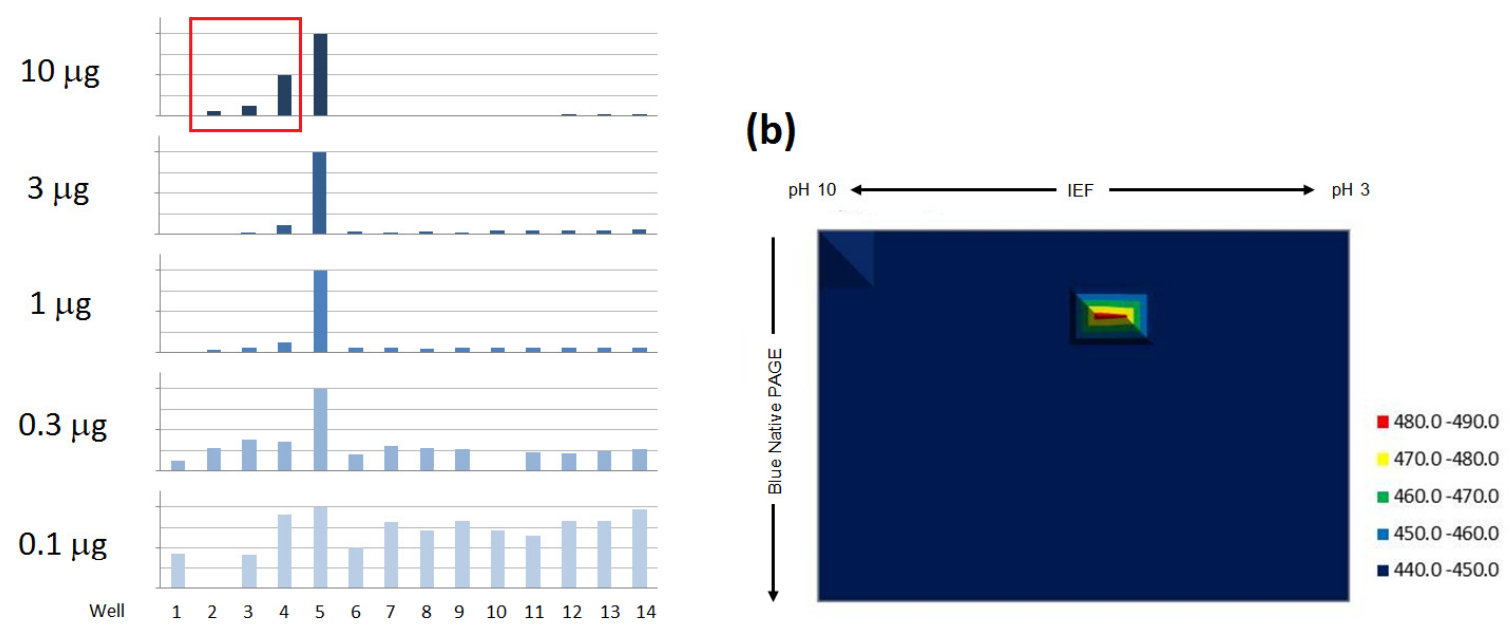

(c)

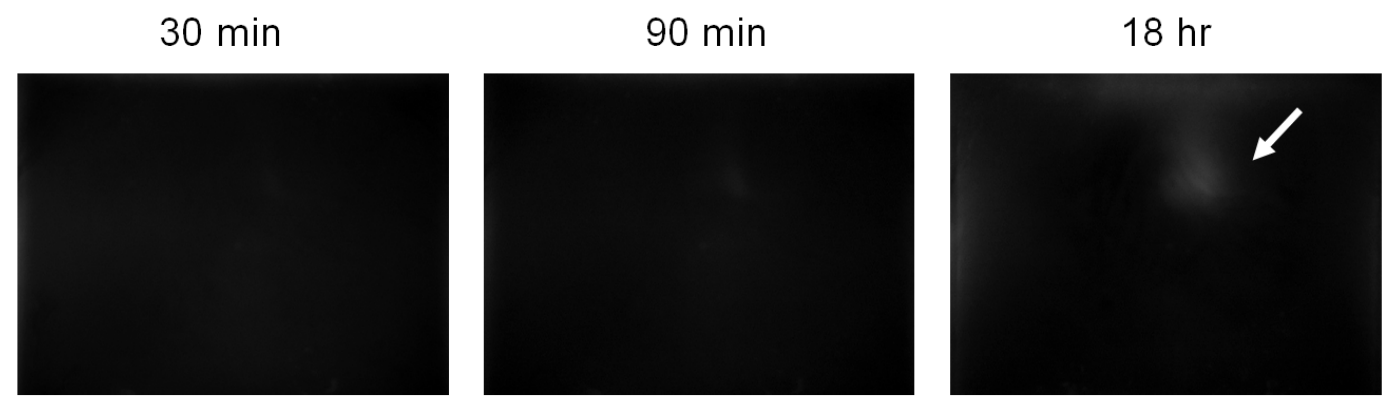

Figure S6. Results of DEG assay of cell lysate of $\beta$-galactosidase-overexpressing HEK293 cells. (a) Normalized fluorescence signals of TG $\beta$-gal detected in one-dimensional DEG assay of $\beta$-galactosidase containing different protein amounts of cell lysate. $\beta$-Galactosidase was electrophoresed in lane 5 , and the red square indicates tailing of the protein. (b) The result of two-dimensional DEG assay of cell lysate of $\beta$ galactosidase-overexpressing HEK293 cells ( $1 \mu \mathrm{g}$ total protein). A good signal-to-noise ratio was achieved after $18 \mathrm{hr}$ incubation. (c) The result of conventional zymography of cell lysate of $\beta$-galactosidase-overexpressing HEK293 cells ( $1 \mu \mathrm{g}$ total protein). A signal was detected after $18 \mathrm{hr}$ incubation. TokyoGreen, the fluorescent product formed from TG $\beta$-gal, is less subject to diffusion than the other fluorescent probes due to its moderate hydrophobicity ${ }^{4}$, but its diffusion was not negligible from the viewpoint of detecting $\beta$-galactosidase activity at longer incubation times. 


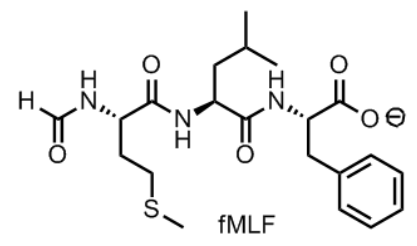

$m / z=438$

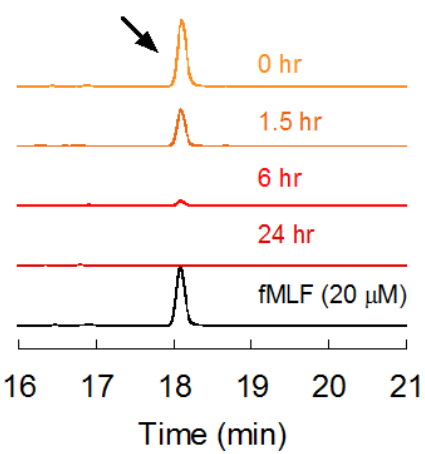<smiles>CSCC[C@H](NC(=O)O)C(=O)[O-]</smiles>

$m / z=178$

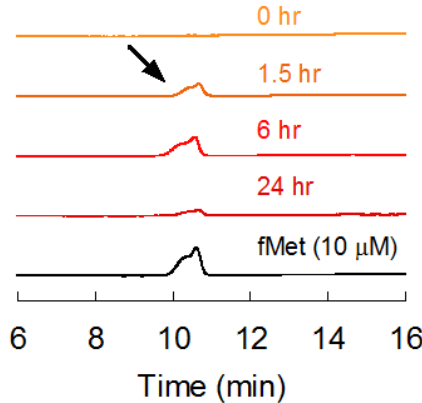

Figure S7. LC-MS-based analysis of fMLF cleavage in mouse liver lysate. fMLF $(20 \mu \mathrm{M})$ was incubated with mouse liver lysate ( $50 \mu \mathrm{g}$ prot. $/ \mathrm{mL}$ ) for the indicated time, and after quenching of the reaction with $10 \%$ formic acid-methanol, samples were injected for LC-MS analysis. 2-Methyl-4-methoxy-TokyoGreen $(0.1 \mu \mathrm{M})$ was used as an internal standard. For fMLF, the chromatogram of $m / z=438 \pm 0.5$ is shown, and for formylmethionine, the chromatogram of $m / z=178 \pm 0.5$ is shown. The black chromatogram indicates the pure compound used as a reference. 


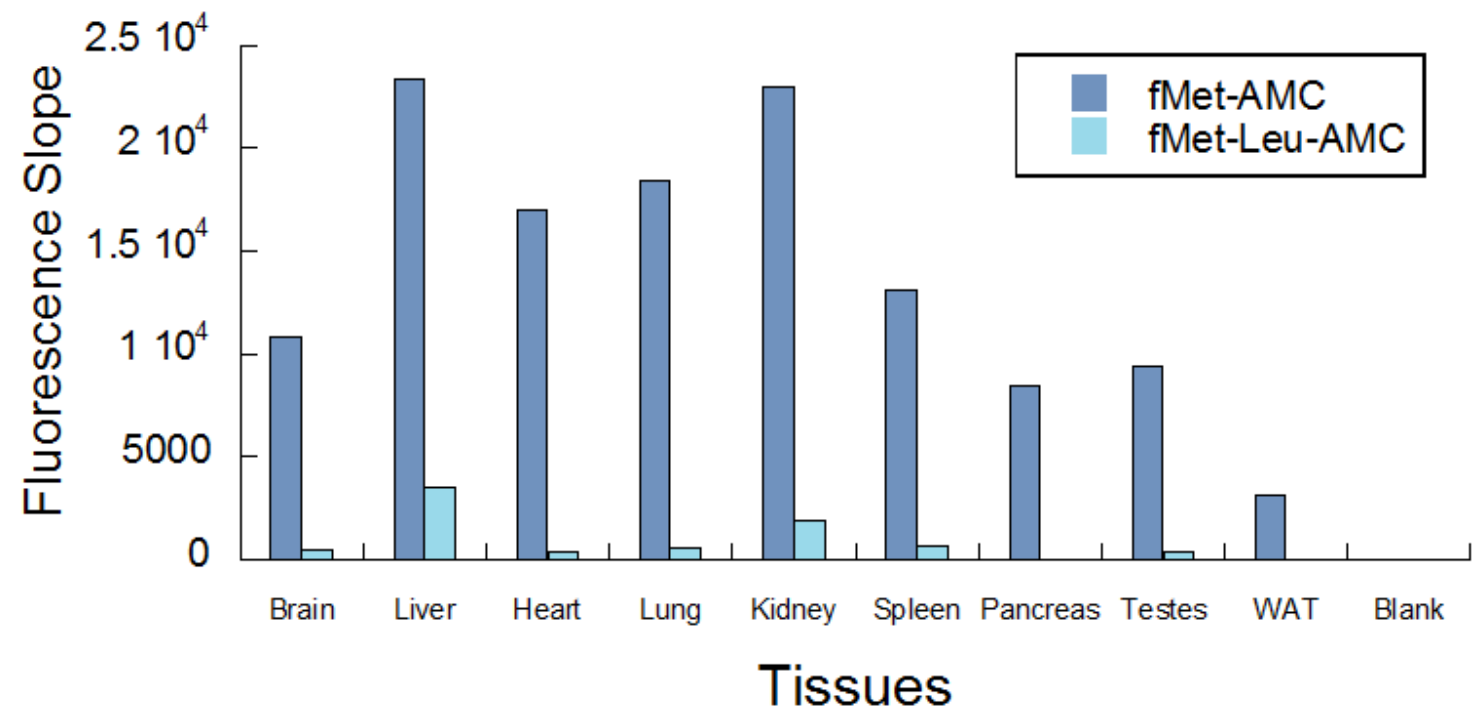

Figure S8. Evaluation of enzymatic activities for fMet-AMC and fMet-Leu-AMC cleavage in mouse tissue lysates. Mouse tissue lysates $(2.5 \mathrm{mg} / \mathrm{mL})$ was mixed with fMet-AMC $(10 \mu \mathrm{M})$ or fMet-Leu-AMC $(10 \mu \mathrm{M})$ in enzyme reaction buffer (pH 7.4 PBS with $1 \mathrm{mM} \mathrm{CaCl}_{2}$ and $1 \mathrm{mM} \mathrm{MgCl}_{2}$ ). Fluorescence increase was monitored for $30 \mathrm{~min}$ with a multiwell plate reader, and the increase rate was calculated. With both probes, high hydrolytic activity was observed in liver and kidney. 
(a)

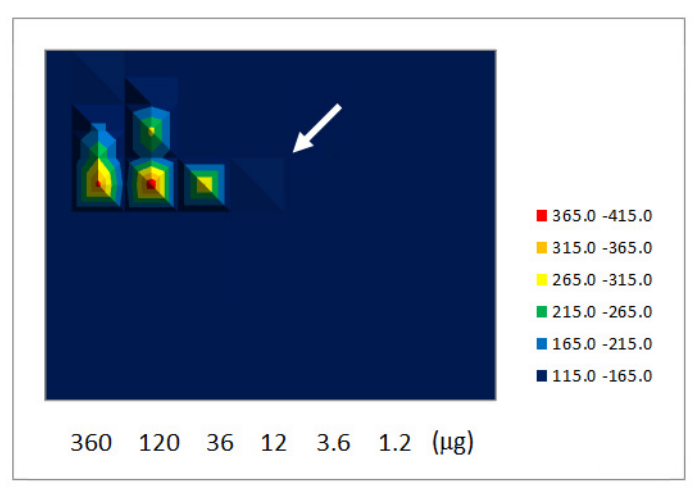

(c)

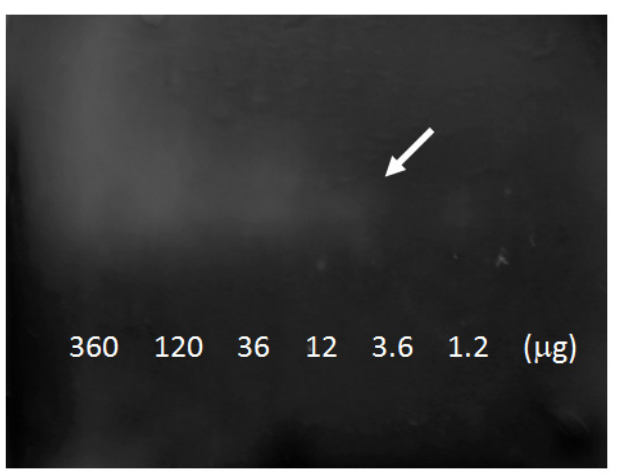

(b)

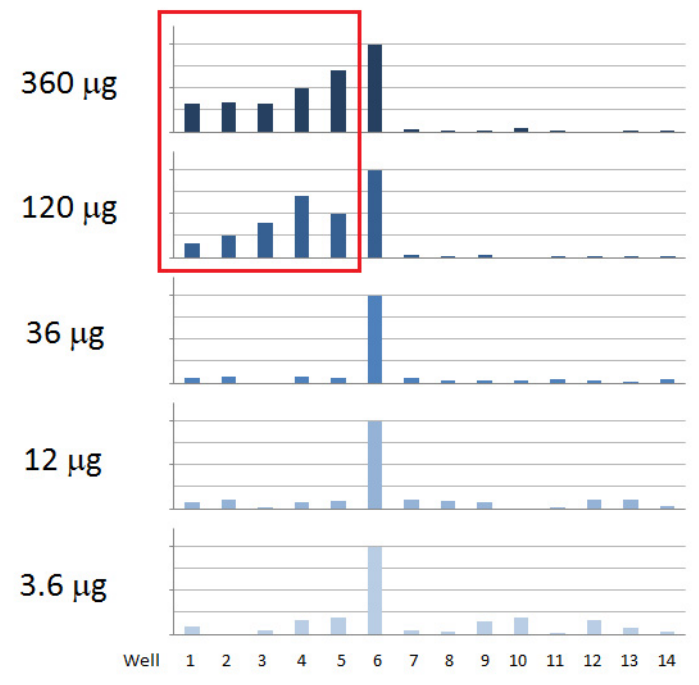

Figure S9. Optimization of protein loading in native PAGE of mouse liver lysate. (a) The result of onedimensional DEG assay of mouse liver lysate (1.2-360 $\mu \mathrm{g}$ total protein) with fMet-AMC (10 $\mu \mathrm{M})$. The white arrow indicates the smallest protein amount in which the signal of fMet-AMC was detectable. (b) Normalized fluorescence signals of fMet-AMC detected in one-dimensional DEG assay of mouse liver lysate with different protein amounts. Active protein (later characterized as APEH) appeared in lane 6, and the red square indicates tailing of the protein. (c) The result of conventional zymography of mouse liver lysate (1.2-360 $\mu \mathrm{g}$ total protein) with fMet-AMC (10 $\mu \mathrm{M})$. A signal was detected after $18 \mathrm{hr}$ incubation, but the signal in the case of $12 \mu \mathrm{g}$ of lysate was barely detectable. 
(a)<smiles>CSCC[C@H](NC(=O)O)C(=O)Nc1ccc2c(C)cc(=O)oc2c1</smiles>

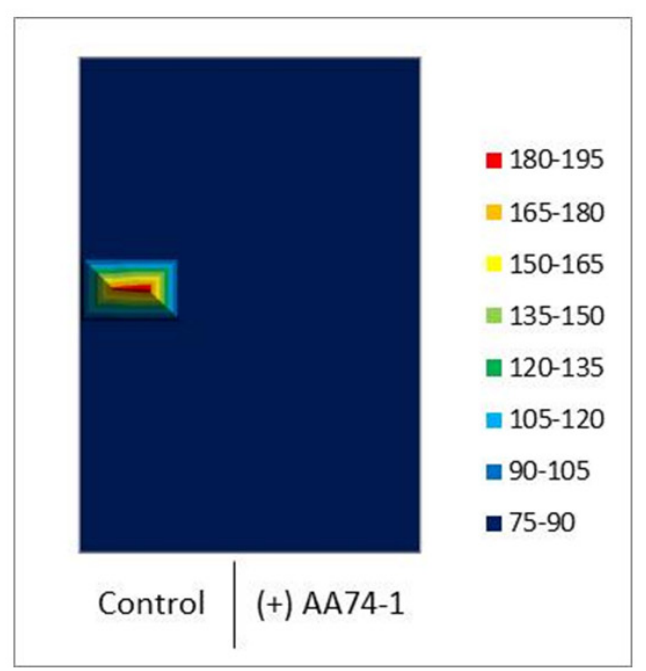

(b)<smiles>CSCC[C@H](NC(=O)[O-])C(=O)N[C@@H](CC(C)C)C(=O)Nc1ccc2c(C)cc(=O)oc2c1</smiles>

fMet-Leu-AMC

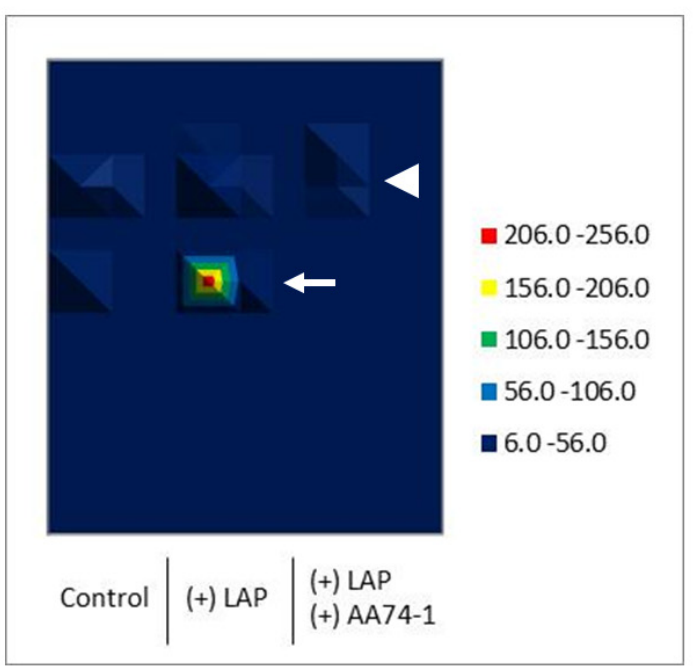

Figure S10. Results of DEG assay of mouse liver lysate with fMet-AMC and fMet-Leu-AMC. Mouse liver lysate ( $25 \mu \mathrm{g}$ total protein) was electrophoresed, and wells from each lane were incubated under different conditions. (a) fMet-AMC (10 $\mu \mathrm{M})$ was used for the assay, and in the case of the right lane, AA74-1 (100 nM) was added $30 \mathrm{~min}$ before the assay. (b) fMet-Leu-AMC (10 $\mu \mathrm{M})$ was used for the assay. In the center and right lanes, leucine aminopeptidase (LAP; $10 \mu \mathrm{g} / \mathrm{mL}$ ) was added, and in the right lane, AA74-1 (100 nM) was also added $30 \mathrm{~min}$ before the assay. Two spots were detected in different molecular weight regions. The smaller one (white arrow) was blocked by AA74-1, and was confirmed to be APEH. The larger one (white arrowhead) was subsequently characterized as proteasome by means of two-dimensional DEG assay (Figures S16, S17). 
<smiles>CSCC[C@H](NC(=O)O)C(=O)Nc1ccc2c(C)cc(=O)oc2c1</smiles>
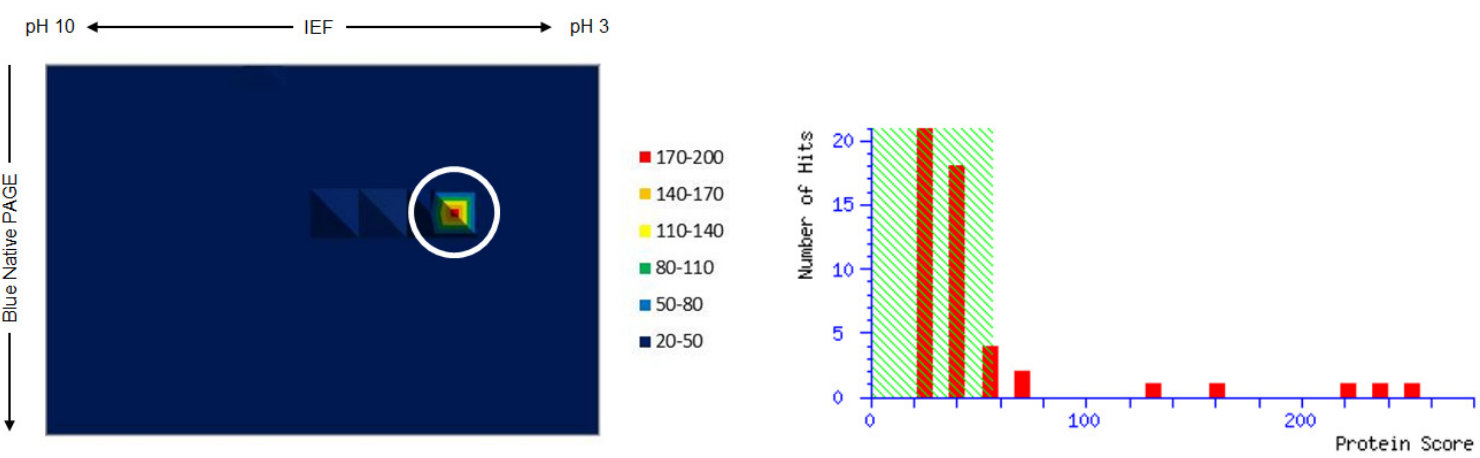
(1) gi|435476
(2) gi|19343726
(3) gi|3318722
(4) gi|189054178
(5) gi|28317
(6) gi|199891
(7) gi|6981420
(8) gi 6911142
(9) gi|16716569
cytokeratin 9 [Homo sapiens]
Acylpeptide hydrolase [Mus musculus
Chain E, Leech-Derived Tryptase InhibitorTRYPSIN COMPLEX
unnamed protein product [Homo sapiens]
unnamed protein product [Homo sapiens]
unnamed protein product [Mus musculus]
anionic trypsin-1 precursor [Rattus norvegicus]
putative glycine-rich RNA binding protein 1 [Catharanthus roseus]
protease, serine, 1 precursor [Mus musculus]
PREDICTED : CUE domain-containing protein 1-like [Sus scrofa]

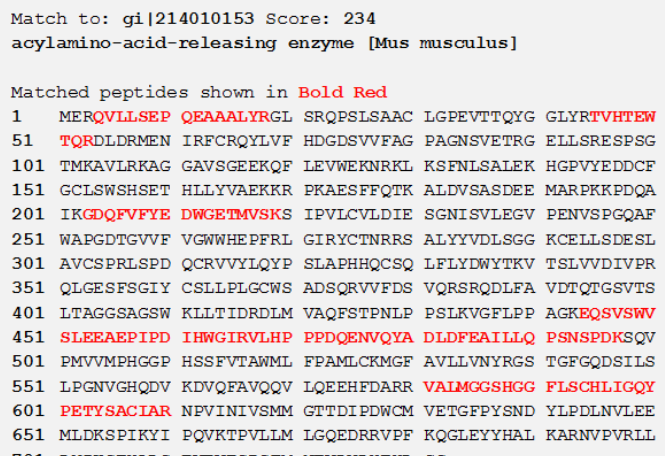

1 MERQVLLSEP QEAAALYRGL SRQPSLSAAC LGPEVTTQYG GLYRTVHTEW

51 TQRDLDRMEN IRFCRQYLVF HDGDSVVFAG PAGNSVETRG ELLSRESPSG

101 TMKAVLRKAG GAVSGEERQF LEVWEKNRKL KSFNLSALEK HGPVYEDDCF

151 GCLSWSHSET HLLYVAEKKR PKAESFFQTK ALDVSASDEE MARPKKPDQA

201 IKGDQFVFYE DWGETMVSKS IPVLCVLDIE SGNISVLEGV PENVSPGQAF

251 WAPGDTGVVF VGWWHEPFRL GIRYCTNRRS ALYYVDLSGG RCELLSDESL

301 AVCSPRLSPD QCRVVYLQYP SLAPHHOCSQ LFLYDWYTKV TSLVVDIVDR

351 QLGESFSGIY CSLLPLGCWS ADSORVVFDS VQRSRQDLFA VDTOTGSVTS

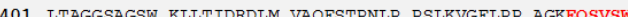

451 SLTAEPI

501 PNV

551 LPGNVGHQDV KDVQFAVQQV LQEEHFDARR VALMGGSHGG FLSCHLIGQ

601 PETYSACIAR NPVINIVSMM GITDIPDWCM VETGFPYSND YLPDLNVLEE

651 MLDKSPIKYI PQVKTPVLLM LGQEDRRVPF KQGLEYYHAL KARNVPVRLI

701 LYPKSTHALS EVEVESDSFM NTVLWLHTHL GS

Figure S11. Result of LC-MS/MS analysis of the target enzyme of fMet-AMC. Gels giving the highest fluorescence signals of fMet-AMC in two-dimensional DEG assay were used for the analysis. APEH (entry 2; score $=232$ ) was the highest-scoring candidate (after exclusion of keratins, present as contaminants) for the target of fMet-AMC. Threshold score $=56(\mathrm{P}<0.05)$. 


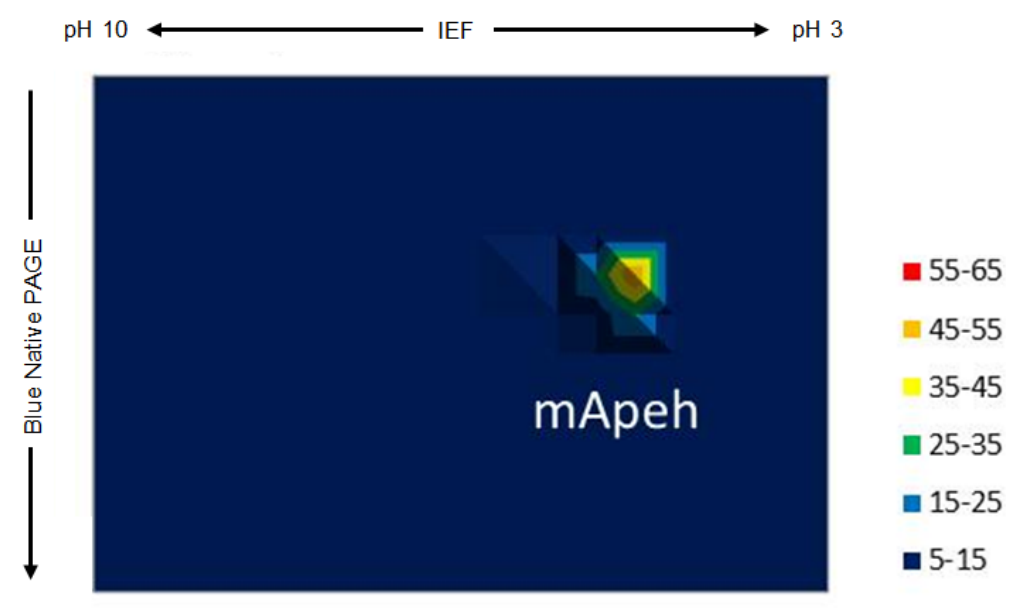

Figure S12. Results of two-dimensional DEG assay of cell lysate of HeLa cells transfected with APEH plasmid. Lysate (10 $\mu \mathrm{g}$ of total protein) was electrophoresed under the same conditions used for mouse liver lysate, and DEG assay was performed with fMet-AMC $(10 \mu \mathrm{M})$. The spot was detected at the same area as in the case of mouse liver lysate (Figure 2d). 
(a)

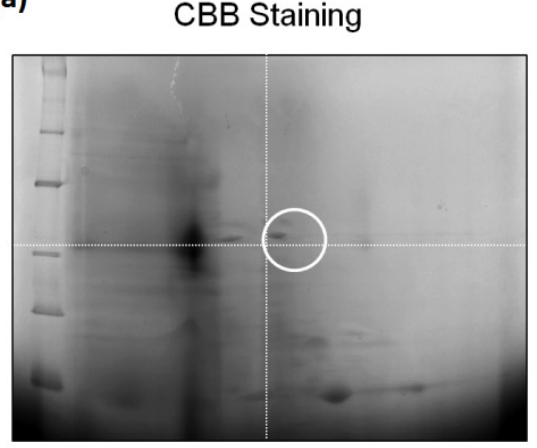

(b)

Western (Anti-APEH)

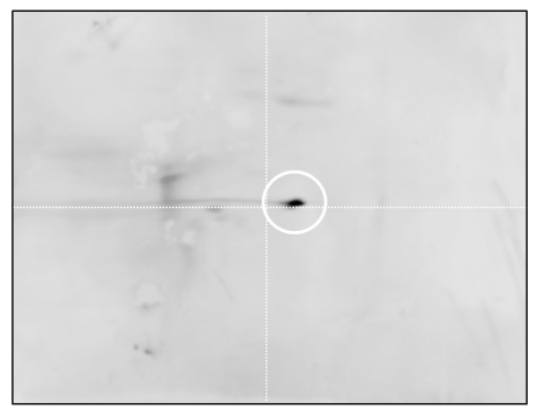

(c) DEG Assay
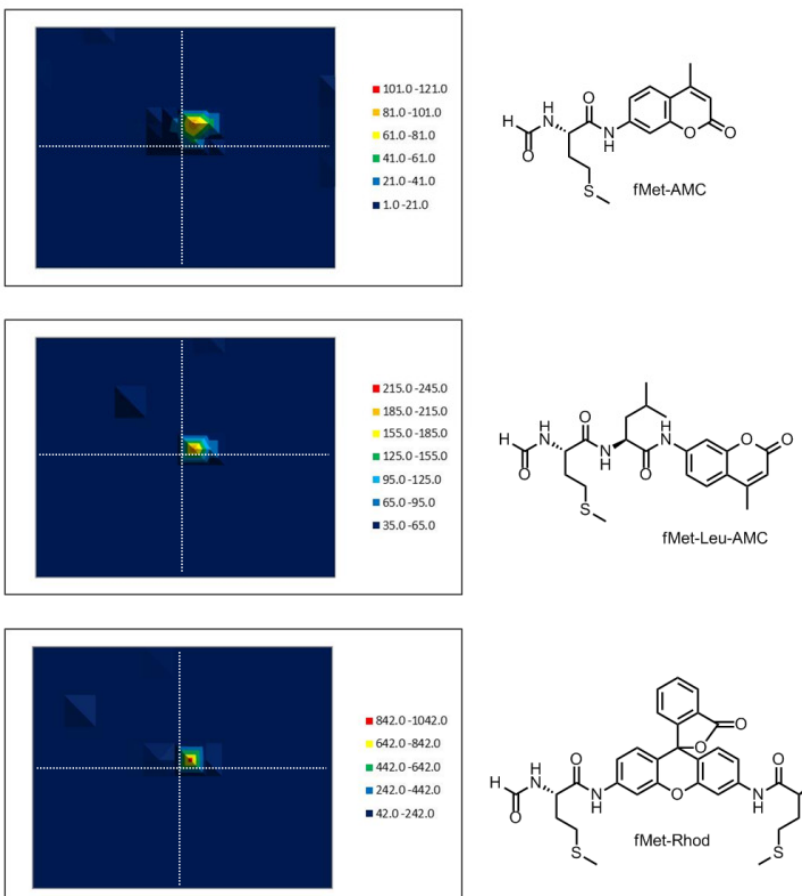
- $642.0-842.0$ $=442.0-642.0$
$=242.0-442.0$ - $242.0-442.0$ - $42.0-242.0$

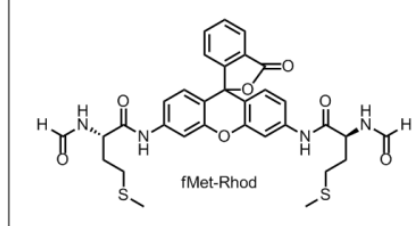

Figure S13. Results of two-dimensional electrophoresis of mouse APEH followed by CBB staining, western blotting, and DEG assay. (a) Result of CBB staining of mouse liver lysate (250 $\mu$ g total protein). (b) Result of western blotting of mouse liver lysate (250 $\mu$ g total protein) with anti-APEH antibody. (c) The result of DEG assays of mouse liver lysate ( $25 \mu \mathrm{g}$ total protein) with fMet-AMC (10 $\mu \mathrm{M})$, fMet-Leu-AMC (10 $\mu \mathrm{M})$, and fMetRhod $(10 \mu \mathrm{M})$. 
(a)

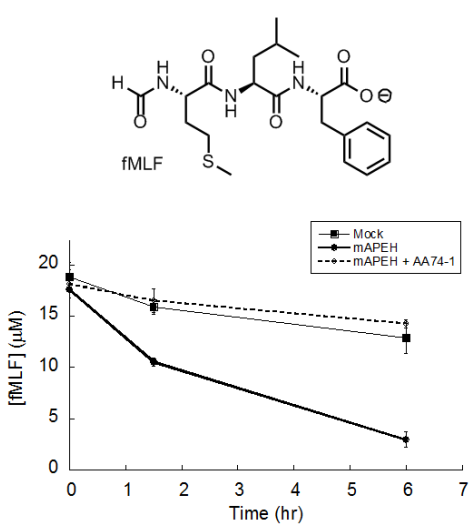

(c)
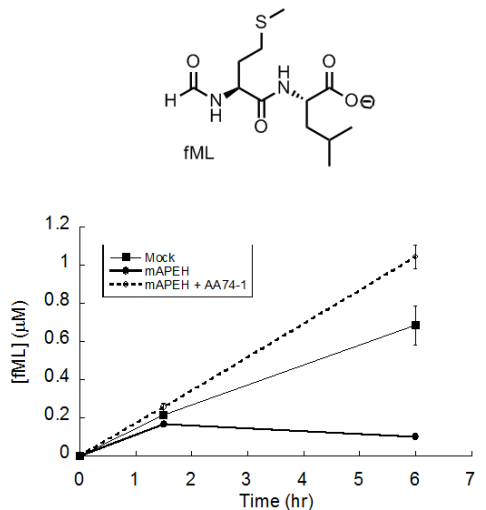

(b)

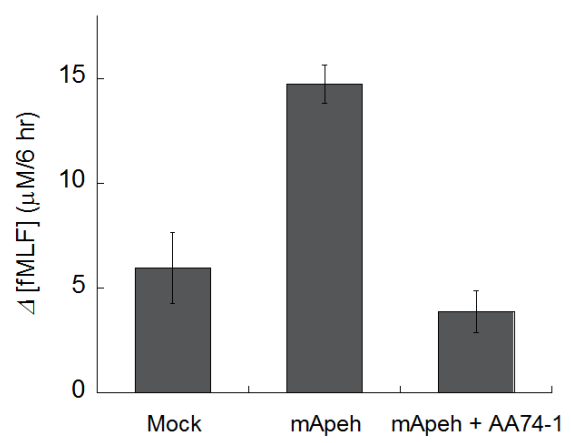

(d)
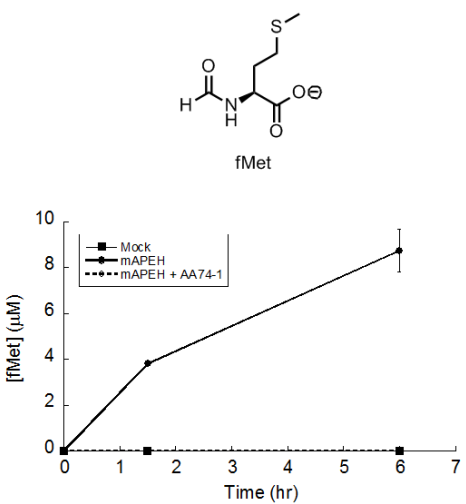

Figure S14. LC-MS-based analysis of fMLF cleavage in lysate of HeLa cells transfected with or without mouse APEH plasmid. Changes of concentration of metabolites were monitored after incubating fMLF (20 $\mu \mathrm{M}$ ) in enzyme reaction buffer ( $\mathrm{pH} 7.4 \mathrm{PBS}$ with $1 \mathrm{mM} \mathrm{CaCl}_{2}$ and $1 \mathrm{mM} \mathrm{MgCl}_{2}$ ) containing cell lysate $(30 \mu \mathrm{g}$ prot./mL). Synthesized formyl-methionyl-leucine (fML) and purchased formyl-methionine (fMet) were used as standards to determine the concentration of each metabolite. (a) Change of fMLF concentration. (b) Quantification of fMLF decrease in (a) after $6 \mathrm{hr}$. (c) Change of fML concentration. (d) Change of fMet concentration. 
(a)

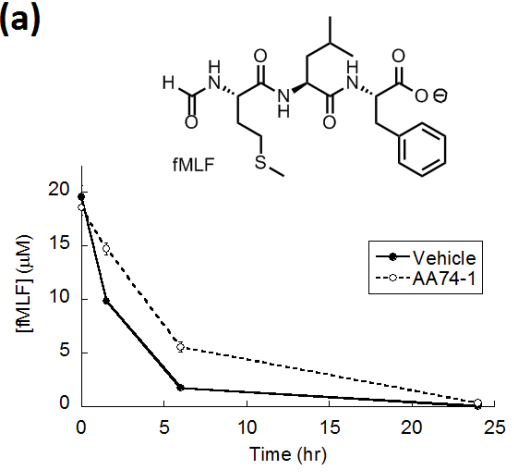

(c)
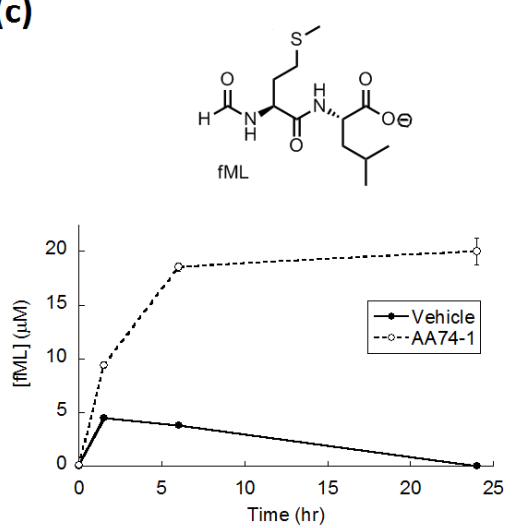

(b)

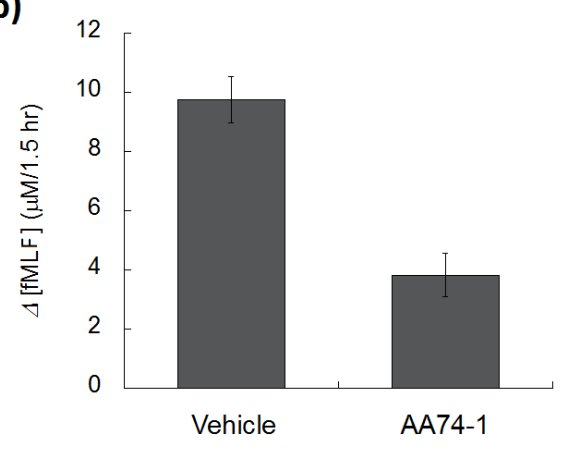

(d)
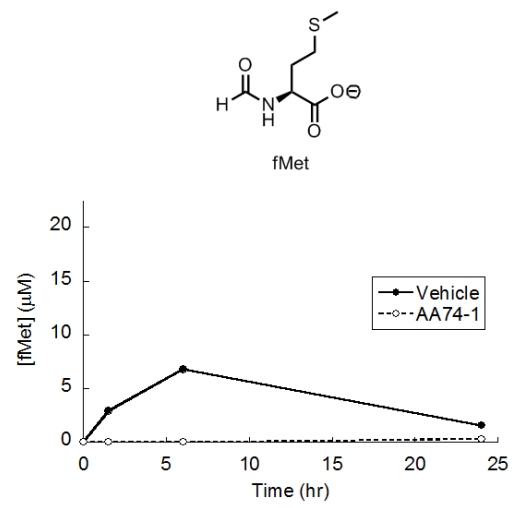

Figure S15. LC-MS-based analysis of fMLF cleavage in mouse liver lysate treated with or without AA74-1.

Changes of concentration of metabolites were monitored after incubating fMLF $(20 \mu \mathrm{M})$ in enzyme reaction buffer ( $\mathrm{pH}$ 7.4 PBS with $1 \mathrm{mM} \mathrm{CaCl} 2$ and $1 \mathrm{mM} \mathrm{MgCl}_{2}$ ) containing mouse liver lysate (50 $\mu$ g protein $/ \mathrm{mL}$ ). (a) Change of fMLF concentration. (b) Quantification of fMLF decrease in (a) after $1.5 \mathrm{hr}$. (c) Change of fML concentration. (d) Change of fMet concentration. 


\section{Characterization of fMet-Leu-AMC cleaving enzyme, acting directly at the C-terminus of formyl-}

methionyl-leucine (fML). In two-dimensional DEG assay of mouse liver lysate with fMet-Leu-AMC, we acquired the list of candidate proteins shown in Figure S16. Proteasome was considered as a candidate, since the target was thought to be enzymes that can hydrolyze peptide bonds. Two subunits of proteasomes, alpha type 3 (entry 12 ; score $=70)$ and beta type $4($ entry 14 ; score $=37)$, were above the threshold score $=36(\mathrm{P}<$ $0.05)$. Further, valosin-containing protein (entry 3; score $=562$ ) is reported to interact strongly with proteasome $26 \mathrm{~S}^{5}$.<smiles>CSCC[C@H](NC(=O)[O-])C(=O)N[C@@H](CC(C)C)C(=O)Nc1ccc2c(C)cc(=O)oc2c1</smiles>

fMet-Leu-AMC
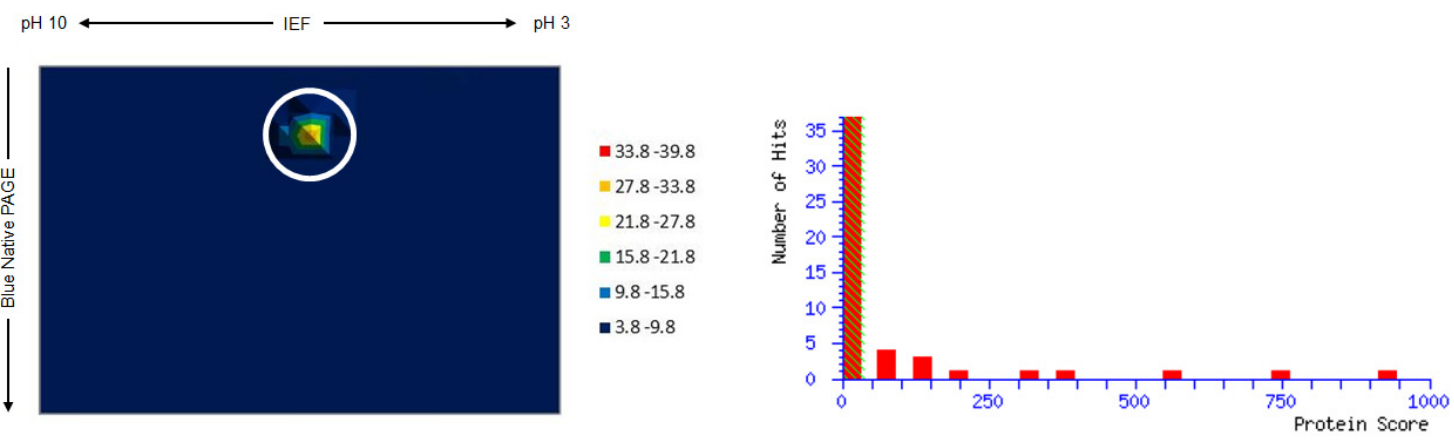

(1) gi|148702861 fatty acid synthase, isoform CRA a [Mus musculus]

(2) gi|29293809 ATP-citrate synthase isoform 2 [Mus musculus]

(3) gi 55217 murine valosin-containing protein [Mus musculus]

(5) gi|74205208 unnamed protein product [Mus musculus]

6) gi|124248512 carbamoyl-phosphate synthase [ammonia], mitochondrial precursor [Mus musculus]

7) gi 13385310 propionyl-CoA carboxylase beta chain, mitochondrial precursor [Mus musculus]

gi|6996911 propining

[Mus musculus]

10) gi 4159806 type II keratin subunit protein [Mus musculus]

(12) gi|12833183 keratin, type II cytoskeletal 71 [Mus mucc

13) gi 150595 unnamed protein product [Mus musculus]

14) gi 14198355 Proteasome (prosome, macropain) subunit, beta type 4 [Mus musculus

(16) gi 148671316

17) gi 150797 unnamed protein product [Mus musculus]

(18) gi $53427 \quad \mathrm{~N}$-myc protein [Mus musculus]

(19) gi $\mid 12326488$

Match to: gi|148704616 score: 70

proteasome (prosome, macropain) subunit,

1 GVGAALEANK RSAACRVSTM SSIGTGYDLS ASTFSPDGRV FQVEYAMKAV

51 ENSSTAIGIR CKDGVVFGVE KLVLSKLYEE GSNKRLFNVD RHVGMAVAG

101 LADARSLADI AREEASNFRS NFGYNIPLKH LADRVAMYVH AYTLYSAVR

151 FGCSPMLGSY SANDGAQLYM IDPSGVSYMR EMTCRDVTE VARIIYIVHD

Match to: gi|14198355 Score: 37

(a) subunit,

beta type 4 [Mus musculus]

1 MEAFWESRAG HWAGGPAPGQ FYRIPSTPSG LMDPASAPCE GPITRTONDM

51 VTGTSVLGVR FDGGVVIAAD MLGSYGSLAR FRNISRIMRV NDSTMLGA

101 DYADFQYLRQ VLGQMVIDEE LLGDGHSYSP RAIHSWLTRA MYSRRSKMNP

151 LWNIMVIGGY ADGESFLGYV DMLGVAYEAP SLATGYGAYI AQPLLREVL

251 QTNWDIAHMI SGFE

of the target enzyme of fMet-Leu-AMC. Gels showing the highest fluorescence signals of fMet-Leu-AMC in two-dimensional DEG assay were used for the analysis. The most likely target was proteasome, of which two subunits (identified peptide sequences are identical in human and mouse; shown in red) appeared in the list. 


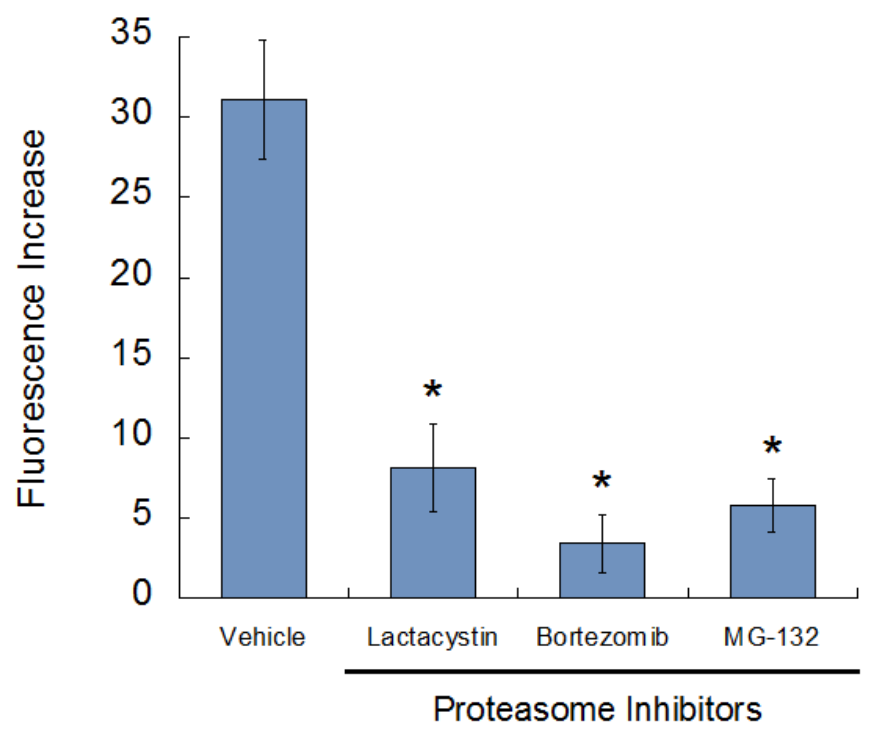

Figure S17. Effect of proteasome inhibitors on DEG assay of mouse liver lysates with fMet-Leu-AMC. Mouse liver lysate ( $25 \mu \mathrm{g}$ total protein) was electrophoresed, and wells from each lane were treated with proteasome inhibitor (lactacystin $1 \mu \mathrm{M}$, bortezomib $1 \mu \mathrm{M}$, or MG-132 $1 \mu \mathrm{M}$ ) for $1 \mathrm{hr}$ before DEG assay with fMet-LeuAMC $(10 \mu \mathrm{M})$. The fluorescence increase of the wells of the target protein (white arrowhead in Figure S10) was plotted. $n=3$ for each condition. Error bar represents S. E.. $*=\mathrm{P}<0.05$.

Selectivity of proteasome inhibitors toward proteasome. In order to study the contribution of proteasome to fMLF metabolism, we used several proteasome inhibitors, i.e., lactacystin ${ }^{6}$, bortezomib ${ }^{7}$, and MG-132 . However, we found that lactacystin also blocks the activity of APEH: the fluorescence increase of fMet-AMC in mouse liver lysate $(250 \mu \mathrm{g} / \mathrm{mL})$ was blocked at higher concentrations of lactacystin, and the calculated $\mathrm{IC}_{50}$ value was close to that for proteasome inhibition (data not shown). Therefore, we used other proteasome inhibitors, bortezomib and MG-132, which did not inhibit APEH activity. In AA74-1-treated mouse liver lysate, these inhibitors blocked the fluorescence increase of fMet-Leu-AMC with apparent $\mathrm{IC}_{50}$ values of $200 \mathrm{nM}$ (bortezomib) and $3 \mu \mathrm{M}$ (MG-132) (Figure S18). These values are higher than those reported for purified enzymes $^{7}$, but similar values of inhibitory constant were observed for proteasome substrate Cbz-Gly-Gly-LeuAMC (for chymotryptic-like activity) under our assay conditions. We think the discrepancy, compared with the reported values, arose because we were using mouse liver lysate containing high concentrations of proteins and other biomolecules. 
(a)

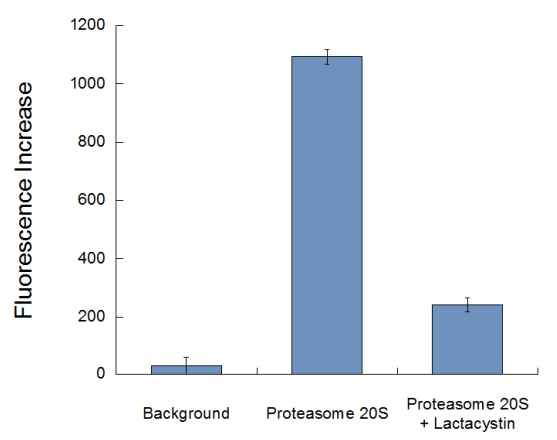

(c)
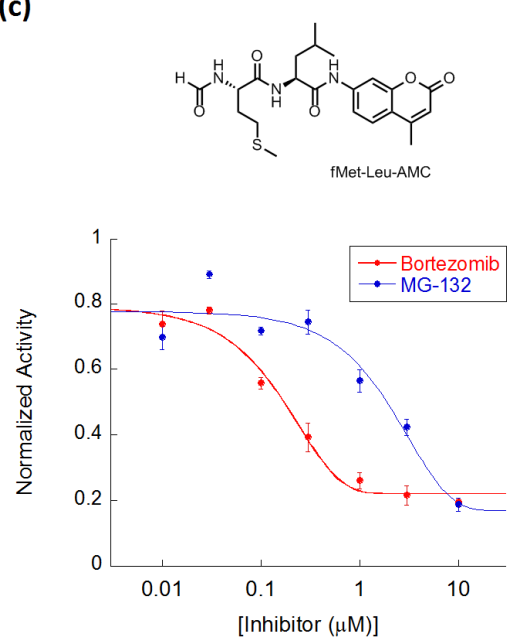

(b)

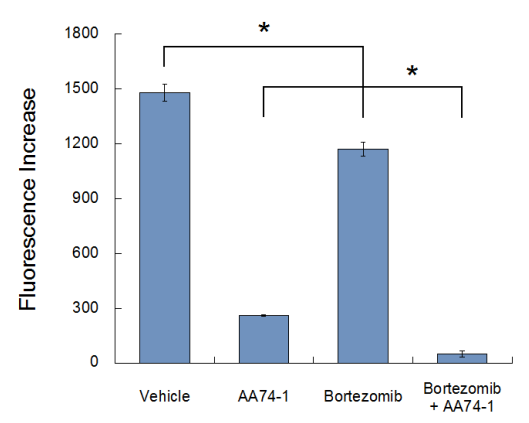

(d)
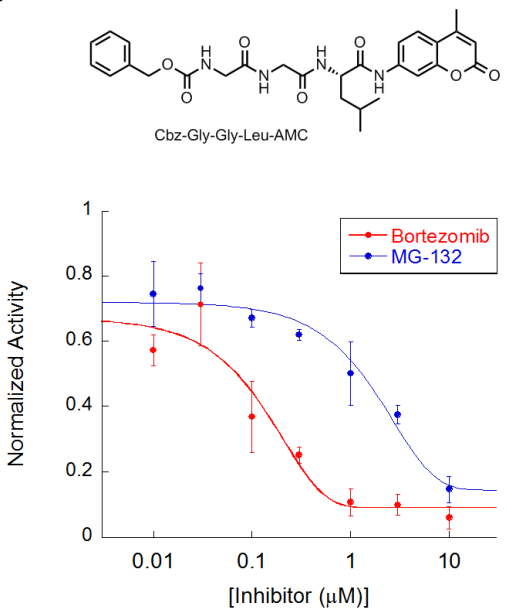

Figure S18. Fluorescence substrate-based evaluation of proteasome activity and inhibition. (a) Fluorescence increase of fMet-Leu-AMC $(10 \mu \mathrm{M})$ incubated with proteasome $20 \mathrm{~S}(10 \mu \mathrm{g} / \mathrm{mL})$ in enzyme reaction buffer $(\mathrm{pH}$ 7.4 PBS with $1 \mathrm{mM} \mathrm{CaCl}_{2}$ and $1 \mathrm{mM} \mathrm{MgCl}$ ). For the inhibitor-treated sample, lactacystin (proteasome inhibitor; $10 \mu \mathrm{M}$ ) was added $2 \mathrm{hr}$ before the assay. (b) Fluorescence increase of fMet-Leu-AMC (10 $\mu \mathrm{M})$ incubated with mouse liver lysate $(250 \mu \mathrm{g} / \mathrm{mL})$ treated with AA74-1 $(100 \mathrm{nM})$ and proteasome inhibitors. * ${ }^{*}$ P $<0.05$. (c) Concentration-dependent inhibition of fluorescence increase of fMet-Leu-AMC (10 $\mu \mathrm{M})$ by proteasome inhibitors (bortezomib and MG-132) in mouse liver lysate treated with AA74-1. (d) Concentrationdependent inhibition of fluorescence increase of proteasome substrate Cbz-Gly-Gly-Leu-AMC (10 $\mu \mathrm{M})$ by proteasome inhibitors in mouse liver lysate treated with AA74-1. 
(a)

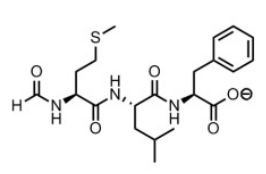

fMLF

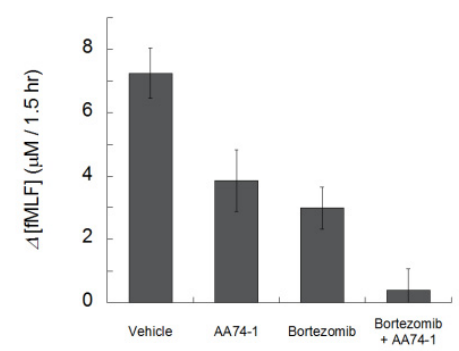

(b)<smiles>CSCC(NC(=O)C=O)C(=O)NCC(C)C</smiles>

fML
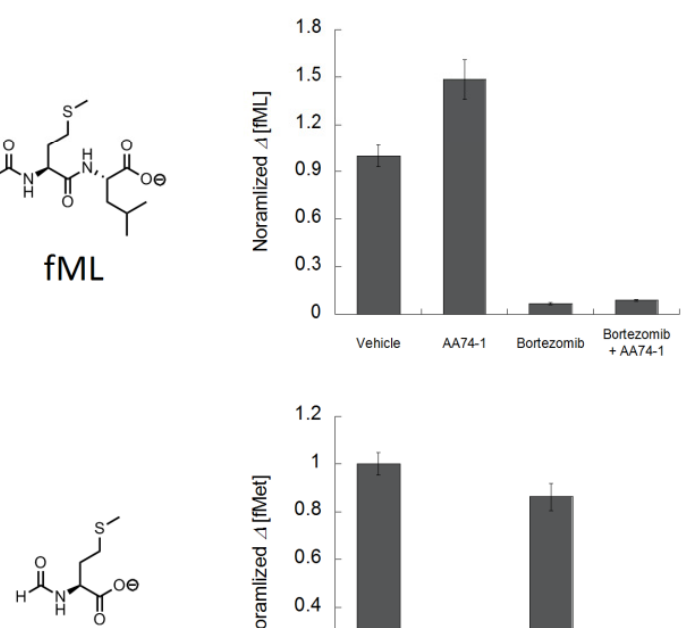

fMet (c)

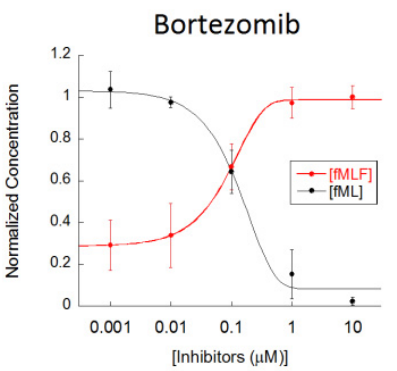

MG-132

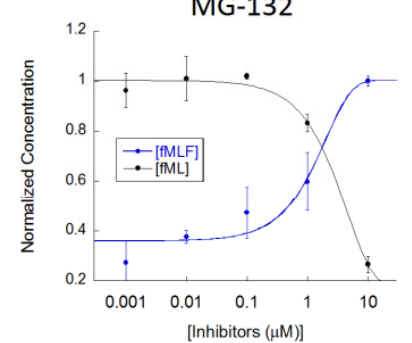

(d)

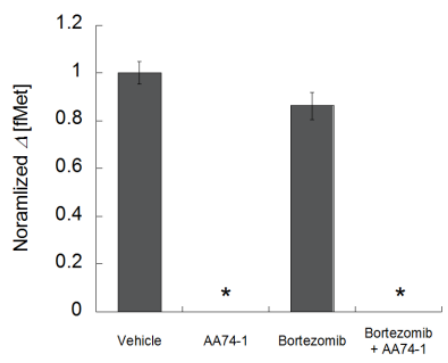

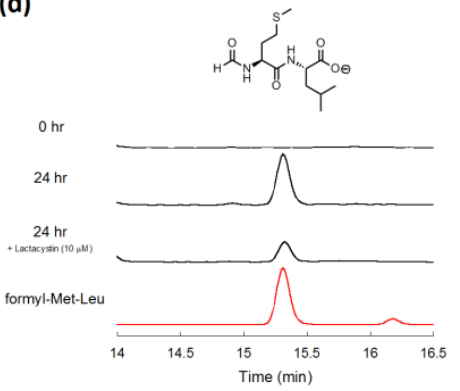

Figure S19. LC-MS-based analysis of fMLF cleavage by proteasome and mouse liver lysate treated with or without proteasome inhibitors. (a) Decrease of fMLF $(20 \mu \mathrm{M})$ after incubation with mouse liver lysate (250 $\mu \mathrm{g} / \mathrm{mL})$ treated with AA74-1 (100 nM), bortezomib $(1 \mu \mathrm{M})$, or both for $1.5 \mathrm{hr}$. (b) Increase of fMLF and fMet in (a). * = Peaks undetectable. (c) Concentration-dependent inhibition of fML formation from fMLF by proteasome inhibitors (bortezomib and MG-132) in mouse liver lysate (250 $\mu \mathrm{g} / \mathrm{mL})$ treated with AA74-1 (100 $\mathrm{nM}$ ). (d) Formation of formyl-leucyl-methionine (fML) after incubation of fMLF (20 $\mu \mathrm{M})$ with proteasome $20 \mathrm{~S}$ $(100 \mu \mathrm{g} / \mathrm{mL})$ for $24 \mathrm{hr}$. Product formation was confirmed by LC-MS, and the mass chromatogram at $m / z=291$ \pm 0.5 is shown. The red chromatogram indicates the pure compound used as a reference. 
(a)

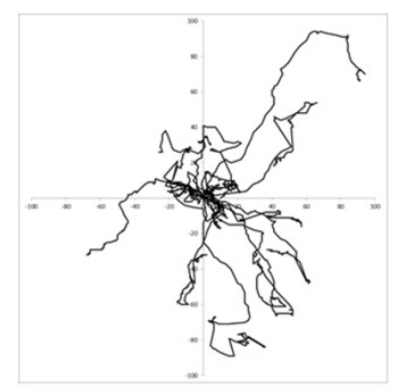

Mock

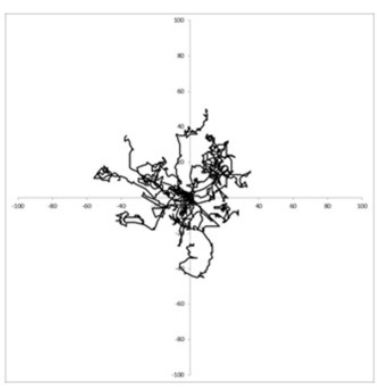

MAPEH

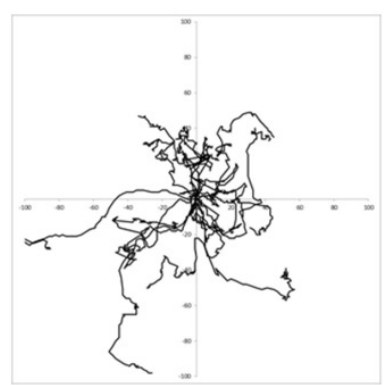

mAPEH + AA74-1

(b)

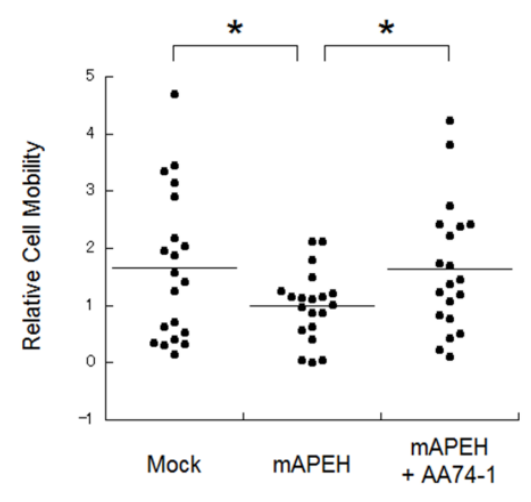

Figure S20. Effect of fMLF metabolism on chemotaxis of differentiated HL-60 cells. fMLF (10 $\mu \mathrm{M})$ was incubated with cell lysate $(30 \mu \mathrm{g} / \mathrm{mL})$ of HeLa cells transfected with or without mAPEH plasmid for $18 \mathrm{hr}$. AA74-1 (100 nM) was used as an inhibitor. The solution was diluted to 1/1000 in HBSS, and added to differentiated HL-60 cells stained with calcein AM (100 nM) on a fibronectin-coated dish. Fluorescence and bright-field images were taken every $15 \mathrm{sec}$ on an IX-71 epifluorescence microscope. (a) Cell traces were analyzed with the motion analysis macro of Metamorph. Traces of 20 cells are shown. (b) Quantification of cell movement in (a). The differences from the original location and that after $22.5 \mathrm{~min}$ were plotted for each condition. $*=\mathrm{P}<0.05$. 
Vehicle

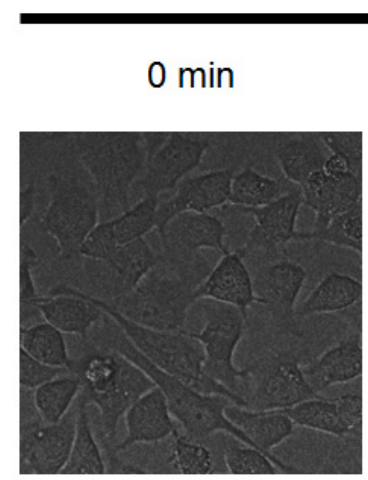

$15 \mathrm{~min}$

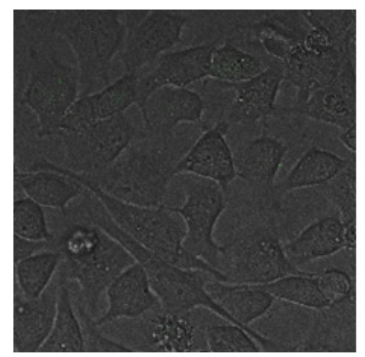

$45 \min$

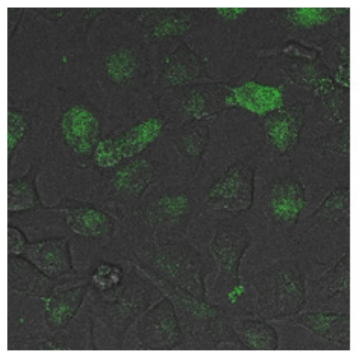

AA74-1 (100 nM)

$45 \min$

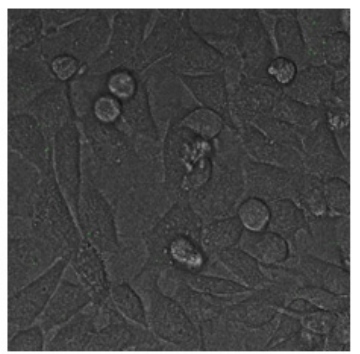

$10-150$

Figure S21. Overlay of bright field and fluorescence images of HeLa cells transfected with mouse APEH and incubated with fMet-Rhod $(10 \mu \mathrm{M})$. AA74-1 (100 nM) was used as an inhibitor. 


\section{Supporting References}

1. Hauert, A. B.; Martinelli, S.; Marone, C.; Niggli, V., Differentiated HL-60 cells are a valid model system for the analysis of human neutrophil migration and chemotaxis. Int. J. Biochem. Cell Biol. 2002, 34 (7), 838-54.

2. Suda, H.; Yamamoto, K.; Aoyagi, T.; Umezawa, H., Purification and properties of N-formylmethionine aminopeptidase from rat liver. Biochim. Biophys. Acta 1980, 616 (1), 60-7.

3. Mallory, P. A.; Travis, J., Human pancreatic enzymes: purification and characterization of a nonelastolytic enzyme, protease E. resembling elastase. Biochemistry 1975, 14 (4), 722-30.

4. Kamiya, M.; Urano, Y.; Ebata, N.; Yamamoto, M.; Kosuge, J.; Nagano, T., Extension of the applicable range of fluorescein: a fluorescein-based probe for Western blot analysis. Angew. Chem. Int. Ed. Engl. 2005, 44 (34), 5439-41.

5. Dai, R. M.; Chen, E.; Longo, D. L.; Gorbea, C. M.; Li, C. C., Involvement of valosin-containing protein, an ATPase Co-purified with IkappaBalpha and $26 \mathrm{~S}$ proteasome, in ubiquitin-proteasome-mediated degradation of IkappaBalpha. J. Biol. Chem. 1998, 273 (6), 3562-73.

6. Fenteany, G.; Standaert, R. F.; Lane, W. S.; Choi, S.; Corey, E. J.; Schreiber, S. L., Inhibition of proteasome activities and subunit-specific amino-terminal threonine modification by lactacystin. Science 1995, 268 (5211), 726-31.

7. $\quad$ Berkers, C. R.; Verdoes, M.; Lichtman, E.; Fiebiger, E.; Kessler, B. M.; Anderson, K. C.; Ploegh, H. L.; Ovaa, H.; Galardy, P. J., Activity probe for in vivo profiling of the specificity of proteasome inhibitor bortezomib. Nat. Methods 2005, 2 (5), 357-62.

Personal Acknowledgements. We especially like to thank the following researchers for kind advice during development of the assay and during experiments.

Prof. Hiroyuki Arai (Graduate School of Pharmaceutical Sciences, The University of Tokyo), Prof. Hidenori Ichijo (Graduate School of Pharmaceutical Sciences, The University of Tokyo), Prof. Takayoshi Okabe (Open Innovation Center for Drug Discovery, The University of Tokyo; OCDD), Prof. Hirotatsu Kojima (OCDD), Assist. Prof. Kazuo Kumagai (OCDD), Dr. Hirofumi Nakano (OCDD), Mr. Shinichiro Egashira (OCDD), Mr. Yukio Tada (OCDD), Ms. Tsukasa Hasegawa (OCDD), Ms. Nae Saito (OCDD), members of the Naatz meeting, and all members of the Nagano lab. 